\title{
High Temperature Selective Sensing of Hydrogen with MgO-Modified $\mathrm{SrMoO}_{4} \mathrm{Micro}^{-}$
} fibers

Engin Çiftyürek $^{a}$, Katarzyna Sabolsky $^{a}$ and Edward M. Sabolsky ${ }^{a}$

\begin{abstract}
Micro-fibers of $\mathrm{Mg}$-doped $\mathrm{SrMoO}_{4}\left(\mathrm{SrMoO}_{4} / \mathrm{MgO}\right)$ were synthesized using a two-step hydrothermal technique. The $\mathrm{SrMoO}_{4} / \mathrm{MgO}$ micro-fibers were used as the sensing material within a solid-state, resistive-type sensor architecture. The material showed selective detection of hydrogen $\left(\mathrm{H}_{2}\right)$ up to $1000^{\circ} \mathrm{C}$ with high sensor response and stability for the given concentrations. The maximum relative resistance change values (Rmax) for $\mathrm{SrMoO}_{4} / \mathrm{MgO}$ for $4000 \mathrm{ppm} \mathrm{H}_{2}$ in a $\mathrm{N}_{2}$ atmosphere $\left(1 \% \mathrm{O}_{2}\right)$ were $-31,-85$, and -87.5 for 600,800 and $1000^{\circ} \mathrm{C}$, respectively. At $1000^{\circ} \mathrm{C}$, and the same background atmosphere, the $R_{\max }$ was only -2.5 and -12.5 to $4000 \mathrm{ppm} \mathrm{CO}$ and $2000 \mathrm{ppm} \mathrm{SO}_{2}$, respectively. Chemical characterization showed that the $\mathrm{Mg}$ was dissolved into the $\mathrm{SrMoO}_{4}$ structure, in addition to residual $\mathrm{MgO}$ precipitate found within the final $\mathrm{SrMoO}_{4}$ powder. The surface $\mathrm{MgO}$ was shown to affect the $\mathrm{H}_{2}$ adsorption and dissociation processes in addition to high selectivity for $\mathrm{H}_{2}$ in comparison to $\mathrm{SO}_{2}$ and $\mathrm{CO}$, while the dissolved Mg contributed to the alteration of the electronic properties, where the Schottky barrier height, band gap, and work function were all lowered. These combined effects resulted in the favorable sensitivity and high selectivity to $\mathrm{H}_{2}$, and also contributed to the increased stability at the elevated sensing temperatures.
\end{abstract}

Key Words: hydrogen sensor, work function, strontium molybdate, magnesium oxide, high temperature

(C) 2017. This manuscript version is made available under the Elsevier user license http://www.elsevier.com/open-access/userlicense/1.0/ 


\section{Introduction}

Hydrogen $\left(\mathrm{H}_{2}\right)$ is a potential clean energy source for the future; however, there are several challenges that need to be overcome before this is achieved. A few of these challenges include the development of clean and efficient approaches for $\mathrm{H}_{2}$ production and storage, and the development of reliable safety measures to monitor storage and utilization systems [1]. For both safety and production technologies, hydrogen sensors are required for low to high temperature. Detection of hydrogen at elevated temperatures is essential for many scientific and industrial applications ranging from fuel cells [2] to metallurgical processes, slagging gasifier, refineries, hydrogenation, automotive exhaust emissions and hydrodesulphurization $[3,4]$ in order to increase overall efficiency where temperatures may exceed $500^{\circ} \mathrm{C}$. One example of a technology that would benefit from the development of high-temperature hydrogen sensors is solid-oxide fuel cells (SOFCs). The SOFC technology has significant importance since it may be used in conjunction with various reformers to efficiently utilize readily available fossil fuels, such as natural gas or coal syngas. Typical SOFCs operate at a temperature between $700-1000^{\circ} \mathrm{C}$. SOFC systems would benefit from real-time monitoring of the $\mathrm{H}_{2}$ concentration on the anode in order to regulate/maintain the required $\mathrm{H}_{2}$ for optimal fuel utilization and control of reforming operations [5]. This is just one example of the near-term need for high-temperature hydrogen sensors. It would be important that these sensors be stable in this temperature range and show low cross-selectivity to other reducing species (such as CO). In addition, since many of the applications discussed above utilize gasses derived from fossil fuel sources, the sensor must be resistant to carbon fouling and poisoning (like that of typical contaminates such as sulfur).

The majority of high temperature, solid-state $\mathrm{H}_{2}$ sensors are designed with a potentiometric architecture, where the active material is based on the fluorite-structured, yttrium-stabilized zirconia (YSZ) or perovskite-structured oxides such as $\mathrm{SrCeO}_{3}, \mathrm{BaCeO}_{3}, \mathrm{SrZrO}_{3}, \mathrm{BaZrO}_{3}$, and $\mathrm{CaZrO}_{3}$ (and various doped combinations) [4]. The major issue with the potentiometric design is the need for a reference electrode, which must be either buried within the sensor architecture (within a complex 
laminate design) or must be isolated outside the testing environment [6]. These restrictions limit the potential placement of the sensor(s) within the testing environment or system. With this in mind, much research has been focused towards the more simplistic resistive-type sensor design which permits minimization of the sensor platform [3]. This type of sensor derives its functionality from surface redox (reduction-oxidation) reactions with a reducing gas (such as $\mathrm{H}_{2}$ ) and surface adsorbed oxygen ions, which results in the donation or elimination of electronic carriers from the sensing material (altering the resistivity of the sensor). The advantage of the design stems from its simplistic and robust design, and the lower electronic measurement requirements for signal acquisition [7, 8]. The typical solid-state, resistivetype sensor is composed of binary oxide semiconductors, such as $\mathrm{SnO}_{2}, \mathrm{NiO}, \mathrm{CuO}, \mathrm{WO}_{3}$, and $\mathrm{V}_{2} \mathrm{O}_{5}$; unfortunately, these compositions are not suitable for high-temperature sensing applications due to stability issues aligned with grain growth/sintering, chemical decomposition/reaction, and reduction processes [3]. Recently, Wildfire et al. stabilized the traditional semiconducting tin oxide $\left(\mathrm{SnO}_{2}\right)$ sensing material used in resistive-type sensors by forming a composite with nano- $\mathrm{Gd}_{2} \mathrm{Zr}_{2} \mathrm{O}_{7}-\mathrm{Gd}_{0.8} \mathrm{Y}_{0.2} \mathrm{Zr}_{2} \mathrm{O}_{7}$, and $\mathrm{Gd}_{1.6} \mathrm{Sm}_{0.4} \mathrm{Zr}_{1.9} \mathrm{Sn}_{0.1} \mathrm{O}_{7}$ composites. These composite materials were used on a micro-scale, resistive-type sensor architecture. Wildfire et al. were able to sense $\mathrm{H}_{2}$ with different $\mathrm{O}_{2}$ background levels up to $1000^{\circ} \mathrm{C}$ by using the refractory zirconate materials to stabilize the $\mathrm{SnO}_{2}$ microstructure and to act as an oxygen support (oxygen source) at high-temperature [9]. However, the authors reported relatively low sensor response values, such as $1-5 \%$ change in resistance upon exposure to $4000 \mathrm{ppm}_{2}$. There are only a few other reports regarding the high-temperature sensing of $\mathrm{H}_{2}$. An operation temperature of $800^{\circ} \mathrm{C}$ has been reported for sensing high concentrations of $\mathrm{H}_{2}$ based on $\mathrm{AlGaN} / \mathrm{GaN}, \mathrm{Si}_{3} \mathrm{~N}_{4}$ and $\mathrm{Ti} / \mathrm{Al} / \mathrm{Mo} / \mathrm{Au}$ metal contact architectures [10]. $\mathrm{Ga}_{2} \mathrm{O}_{3}$ exhibited high sensitivity for $\mathrm{H}_{2}, \mathrm{CH}_{4}$, and $\mathrm{CO}$ at temperatures starting from $500^{\circ} \mathrm{C}$ to $1000^{\circ} \mathrm{C}$; the researchers attempted to improve selectivity by applying an alternative catalyst, as well as, physical filters aligned with the demand dictated by the environment [11]. Chen et al. reported the successful testing of ppm levels of $\mathrm{H}_{2}$ at $500^{\circ} \mathrm{C}$ with a $20 \% \mathrm{O}_{2}$ testing environment using $\mathrm{TiO}_{2}$ supported on $\mathrm{Al}_{2} \mathrm{O}_{3}$ [12]. Lloyd-Spetz et al. developed metal-insulator-SiC devices in both capacitor and Schottky diode configurations, and showed successful operation at $1000^{\circ} \mathrm{C}$ with operation for several 
weeks at $600^{\circ} \mathrm{C}$ against hydrocarbons and $\mathrm{H}_{2}$ (with an $\mathrm{O}_{2}$ background less than $0.7 \%$ ). This demonstration was one of the most successful in literature, but the sensor still had some limitations due to potential oxidation of $\mathrm{SiC}$ at elevated temperature and high oxygen background $\left(\geq 1 \% \mathrm{O}_{2}\right)$. The other limiting factors arise from sensor architecture that requires a complicated/multistep microelectromechanical system (MEMS) manufacturing process in addition to costly single crystal SiC sensing material [13].

Chemical and microstructural modifications of the sensing materials are the basic strategies to improve the relative sensitivity of resistive-type sensors. In the case of microstructural modification, the prime method is to reduce the grain size (increase surface area) of the sensing material by utilizing nanomaterials (particulate or thin film microstructures). In some cases, various high surface area nanoparticle morphologies were engineered by modifying local surface energy or by using a sacrificial template $[14,15]$. This strategy usually results in further enhancement of the surface area, and thus, increased catalytic activity and sensor response. Unfortunately, these strategies are not applicable in the case of temperatures higher than $500^{\circ} \mathrm{C}$ due to sintering/coarsening mechanisms and enhanced reduction rates (due to the high surface area). In this work, a $\mathrm{SrMoO}_{4} / \mathrm{MgO}$ nano-composite composition was synthesized into micro-fibers using a hydrothermal process. The MgO-modified $\mathrm{SrMoO}_{4}$ was tested for $\mathrm{H}_{2}$ detection at $600-1000^{\circ} \mathrm{C}$, and the porous fiber microstructure was found to remain stable after the sensor testing. The current authors (Ciftyurek et al.) previously tested $\mathrm{SrMoO}_{4}$ for high-temperature $\mathrm{SO}_{2}$ and $\mathrm{H}_{2} \mathrm{~S}$ sensing on a resistive-type sensor platform, where the sensing materials demonstrated reasonable stability and adequate sensing of the sulfur species up to $1000^{\circ} \mathrm{C}$ [16]. Interestingly in the previous work, the $\mathrm{SrMoO}_{4}$ composition, without the $\mathrm{MgO}$ addition, showed low sensitivity to $\mathrm{H}_{2}$.

The current work investigated the effect of $\mathrm{MgO}$ addition/doping to the $\mathrm{SrMoO}_{4}$ in order to form a porous, $\mathrm{MgO}$-enhanced $\mathrm{SrMoO}_{4}$ composition with selectivity towards $\mathrm{H}_{2}$. The selection criterion for $\mathrm{MgO}$ was based on the fact that it is a known $\mathrm{H}_{2}$ dissociation catalyst [17], as well as, a support in transesterification, double-bond isomerization, self- and cross-condensation reactions [18, 19]. A 
secondary $\mathrm{MgO}$ phase on the $\mathrm{SrMoO}_{4}$ would catalytically modify the $\mathrm{SrMoO}_{4}$ surface which would potentially increase reversible $[20,21,22]$, homolytic $[23,24]$, and/or heterolytic $[25,26]$ dissociative adsorption processes towards $\mathrm{H}_{2}[27,20,28,29]$ and $\mathrm{H}_{2}$ uptake capability [30, 31, 32].

The composite $\mathrm{SrMoO}_{4} / \mathrm{MgO}$ composite was synthesized using a two-step hydrothermal process in order to control the $\mathrm{MgO}$-content in the $\mathrm{SrMoO}_{4}$ and to control the macroscopic morphology of the sensor material. The two-step process included the formation of acicular (fiber)-shaped $\mathrm{MgO}$ particles in the initial hydrothermal step. The intent was to use these $\mathrm{MgO}$ particles as templates to topotaxially grow $\mathrm{SrMoO}_{4}$ films over these particles in a second hydrothermal step. This process would permit the formation of a $\mathrm{SrMoO}_{4} / \mathrm{MgO}$ composite, while potentially $\mathrm{Mg}$-doping of the $\mathrm{SrMoO}_{4}$ could concurrently occur due to dissolution/re-precipitation of the $\mathrm{Mg}$ in the aqueous medium. In addition, it was perceived that a portion of the acicular morphology of the $\mathrm{MgO}$ templates would remain after the $\mathrm{SrMoO}_{4}$ reaction. The acicular morphology would limit potential grain growth and sintering processes at high temperature. The current paper describes the synthesis and final chemistry/structure of the described $\mathrm{SrMoO}_{4} / \mathrm{MgO}$ composite, as well as, the electronic characteristics of this material. This characterization was correlated to the sensing response of the material to $\mathrm{H}_{2}, \mathrm{CO}$, and $\mathrm{SO}_{2}$ on a resistive-type sensor platform at temperatures $\geq 600^{\circ} \mathrm{C}$.

\section{Experimental}

\subsection{Synthesis of $\mathrm{SrMoO}_{4} / \mathrm{MgO}$ Fibers}

The MgO micro-fibers were synthesized by a hydrothermal method based partially on a procedure reported elsewhere [33]. The $\mathrm{MgO}$ micro-fibers were synthesized using $6.44 \mathrm{~g}$ magnesium acetate (magnesium acetate tetrahydrate, ACS, 98.0-102.0\%, CAS 16674-78-5, Alfa Aesar) and 1.2 g urea (ACS, 99.0-100.5\%, CAS 57-13-6, Alfa Aesar) within de-ionized $\mathrm{H}_{2} \mathrm{O}$. These salts were combined within a 300 ml Teflon ${ }^{\mathrm{TM}}$ lined autoclave (401A-8336, Autoclave Engineers, PA, USA), and the hydrothermal reaction was completed at $200^{\circ} \mathrm{C}$ for $3 \mathrm{~h}$. The $\mathrm{SrMoO}_{4}$ growth on the $\mathrm{MgO}$ micro-fibers was completed in a second hydrothermal step which included the addition of $0.027 \mathrm{~g} \mathrm{MgO}$ micro-fibers to $40 \mathrm{ml}$ deionized 
(DI) water; the $\mathrm{pH}$ of the suspension was adjusted to 6 by dropwise addition of nitric acid $\left(\mathrm{HNO}_{3}\right)$. Strontium nitrate $\left(\mathrm{Sr}\left(\mathrm{NO}_{3}\right)_{2}\left(99.0 \%\right.\right.$, Alfa Aesar) and ammonium molybdate $\left(\left(\left(\mathrm{NH}_{4}\right)_{6} \cdot \mathrm{Mo}_{7} \mathrm{O}_{24}\right) \cdot 4 \mathrm{H}_{2} \mathrm{O}\right.$, 99\%, Alfa Aesar) were dissolved into deionized (and de-carbonized) water in separate beakers. After mixing the two solutions with the $\mathrm{MgO}$ suspension, the $\mathrm{pH}$ of final clear solution was altered to 8 by the addition of ammonia hydroxide $\left(\mathrm{NH}_{4} \mathrm{OH}\right)$. The final product was transferred into the same $300 \mathrm{ml}$ Teflon ${ }^{\mathrm{TM}}$ lined autoclave (used for the $\mathrm{MgO}$ micro-fiber synthesis) and processed at $80^{\circ} \mathrm{C}$ for $8 \mathrm{~h}$ with a $3{ }^{\circ} \mathrm{C}$ heating and cooling rate for nano- $\mathrm{SrMoO}_{4}$. The details of the effect of alteration in the $\mathrm{pH}$, solute ion concentration, and hydrothermal processing time and temperature on the morphology of nano- $\mathrm{SrMoO}_{4}$ were discussed elsewhere by the current authors [16].

\subsection{Sensor Fabrication and Testing Protocol}

The sensor device utilized in this work was composed of alumina $\left(\mathrm{Al}_{2} \mathrm{O}_{3}\right)$ substrates, platinum (Pt) inter-digitized electrodes (IDEs) and the $\mathrm{SrMoO}_{4} / \mathrm{MgO}$ sensing layer. The sensing material was screenprinted to a thickness of $\sim 300 \mu \mathrm{m}$ and subsequently fired at $1200^{\circ} \mathrm{C}$ in air to promote the adhesion. The testing gas composition was adjusted by individual mass flow controllers (MFCs, Sierra Instruments). A Keithley 2700 Multimeter was used to supply a 5-10 $\mu \mathrm{A}$ DC current in a two-point resistance configuration. A LabView ${ }^{\circledR}$ program controlled the testing and data acquisition in order to simultaneously read gas flow rate, temperature and resistance of the sensor during testing. The sensor response, cross-selectivity, and response/recovery times were characterized. The relative resistance change $(R)$ is expressed as an alteration in the baseline resistance of a metal-oxide sensing material upon introduction of the target gas. The relative resistance was calculated using the equation presented in Eq. 1. The $R$ denotes the relative change in resistance, where $R_{B}$ is the resistance in $1 \% \mathrm{O}_{2}$ balanced with pure $\mathrm{N}_{2}$, while $R_{E}$ is the resistance value during exposure to the target gas.

\section{[Eq. 1]}

The response time is described as the time that passes for the sensor to reach $90 \%$ of the total resistance change. If the relative resistance change is a negative value, then the sensor response will be 
designated in this paper as an " $n$-type response"; if the $R$ is a positive value, then the sensor response will be termed as a "p-type response". The absolute maximum of the relative resistance change will be termed as the $R_{\max }$ throughout the work. The gas exposure cycle used throughout the work was presented as insets within the measurement figures, which include the concentration of the target gas and time of exposure during holds at the designated temperatures. In all tests, the total flow was adjusted to $50 \mathrm{sccm}$ by adjusting the flow of $\mathrm{H}_{2}, \mathrm{CO}, \mathrm{SO}_{2}, \mathrm{~N}_{2}$ and $\mathrm{O}_{2}$ via the mass flow controllers (MFCs). Three different concentration levels of target gas, balanced with high purity nitrogen $\left(\mathrm{N}_{2}, 99.99 \%\right.$, Matheson Ultra High Purity grade), were tested at three different exposure times. During time dependent sensing experiments, the sensors were heated and held at $600^{\circ} \mathrm{C}, 800^{\circ} \mathrm{C}$, and $1000^{\circ} \mathrm{C}$ for $8.5 \mathrm{~h}$, and the gas exposure cycle presented in the figures was applied. The sensors were cooled to room temperature under atmospheric conditions. In a few occasions, the sensor was cooled under $\mathrm{N}_{2}$ flow in order to conduct chemical state analysis on the sensing material. Matheson Research grade $99.998 \% \mathrm{O}_{2}$ was used in this work. As seen in the inset plots for $\mathrm{H}_{2}$ testing, the exposure cycle increased the ppm level of $\mathrm{H}_{2}$ from 1000 to 2000, and then to $4000 \mathrm{ppm}$, and then the concentration was decreased back down to $1000 \mathrm{ppm}$. Each of these gas concentrations were held for $20 \mathrm{~min}$ and then the pyramid was repeated with a hold time of $5 \mathrm{~min}$. A final pulse of the maximum concentration was placed on the sensors for 30,15 , and $5 \mathrm{~s}$ to test the limits of the response/recovery kinetics. Each of these pulses were balanced with pure $\mathrm{N}_{2}$ (with $1 \% \mathrm{O}_{2}$ background) during the isothermal hold. A 30 min holding time in the $1 \% \mathrm{O}_{2}+\mathrm{N}_{2}$ mixture was placed on the sensors between each pulse in order to allow the sensors to recover before further exposure testing. Potential interfering gases, $\mathrm{SO}_{2}$ and $\mathrm{CO}$, were included in the cross-selectivity tests for $\mathrm{SrMoO}_{4} / \mathrm{MgO}$ with the same exposure cycle applied for $\mathrm{H}_{2}$.

\subsection{Sensing Material Characterization}

The chemical composition and nano/micro-structure of the developed sensing materials were characterized by means of JEOL 7600F scanning electron microscopy (SEM) attached with Oxford INCA 350 energy dispersive X-ray spectroscopy (EDS), X-ray and ultraviolet photoelectron spectroscopies 
(XPS PHI 5000 Versaprobe) and UPS), atomic absorption spectroscopy (AAS), X-ray diffraction (XRD) (a Panalytical X-Pert Pro diffractometer PW 3040 Pro and temperature programmed reduction (TPR). SEM-EDS and XRD were utilized to observe the microstructure and determine the crystallinity of the assynthesized product. XPS was used for quantification and chemical state analysis of the constituent elements on the surface and through the thickness of the micro-fibers. Temperature programmed reduction (TPR) was used to better understand the different $\mathrm{H}_{2}$ adsorption/dissociation/consumption behaviors of the nano- $\mathrm{SrMoO}_{4}$ and $\mathrm{SrMoO}_{4} / \mathrm{MgO}$. Atomic absorption spectroscopy (AAS) was employed to precisely determine the atomic concentration of the $\mathrm{Mg}$ in $\mathrm{SrMoO}_{4}$. A solid-solution forming between the nano-SrMoO 4 and the $\mathrm{MgO}$ micro-fiber substrate would affect the band-gap and work function $(\Phi)$, thus the $\mathrm{SrMoO}_{4} / \mathrm{MgO}$ material was subjected to further UV-Vis (ultraviolet-visible spectroscopy) in order to measure the band-gap $\left(\mathrm{E}_{\mathrm{g}}\right)$. UPS spectrum was utilized to measure the work function of both the sensing and platinum electrode materials. The activation energy calculations were carried out in order to quantify the Schottky barrier heights among the grains, while a work function based approximation is

used to determine the Schottky barrier height between the inter-digitated metallization and sensing material interface.

\section{Results and Discussion}

\subsection{Microstructural Characterization of the $\mathrm{SrMoO}_{4} / \mathrm{MgO}$ Fibers}

Fig.1-a shows the SEM micrograph of the as-synthesized $\mathrm{MgO}$ micro-fibers. The XRD data showed that the $\mathrm{MgO}$ micro-fibers displayed a high level of crystallinity (data not included). All of the measured peaks were indexed using the standard \#87-0653 card from the Joint Committee on Powder Diffraction Standards (JCPDS) for $\mathrm{MgO}$. The $\mathrm{MgO}$ micro-fibers differ in radius from $100 \mathrm{~nm}$ to $1 \mu \mathrm{m}$. Fig.1-b displays the SEM micrograph of the $\mathrm{SrMoO}_{4}$ decorated over the $\mathrm{MgO}$ micro-fibers at low magnification while the inset provides a high magnification micrograph of the fiber surface. The micro-fibers of $\mathrm{SrMoO}_{4} / \mathrm{MgO}$ displayed a similar acicular morphology as the original $\mathrm{MgO}$ fibers. The nano-sheet features of the $\mathrm{SrMoO}_{4} / \mathrm{MgO}$ were shown to be homogeneous through the synthesized material. In order 
to rapidly assess high temperature stability of the seeded growth material, the $\mathrm{SrMoO} / \mathrm{MgO}$ was heated to $1000^{\circ} \mathrm{C}$ and held for $5 \mathrm{~h}$. The resulting microstructure is presented in the SEM micrograph shown in Fig.1-c. The microstructure of the $\mathrm{SrMoO}_{4} / \mathrm{MgO}$ micro-fibers was generally resistant to the effects of the high temperature treatment. The spongy microstructure with the extended and homogeneous porosity network was preserved; however, the grain growth still occurred with some limited sintering. The grain size of the $\mathrm{SrMoO}_{4} / \mathrm{MgO}$ micro-fibers was in the range of 1 to $10 \mu \mathrm{m}$. For comparison purposes, Fig.1-d shows the SEM image of the nano- $\mathrm{SrMoO}_{4}$ (without $\mathrm{MgO}$ ) after a $5 \mathrm{~h}$ heat treatment at $1000^{\circ} \mathrm{C}$. Image analysis was conducted in order to quantify the porosity using a 2D binary reconstruction analysis of the SEM images; the analysis showed that after firing, the porosity was $\sim 52 \%$. For the given sensor application, it is of great importance to maintain this highly porous network at high temperature in order to present a high level of active redox area and also to eliminate diffusional limitations of the target gas [34]. Overall, this open microstructure permits the whole volume of the sensing material to be open to interaction with the hydrogen. The nano- $\mathrm{SrMoO}_{4}$ decorated over $\mathrm{MgO}$ will be termed as $\mathrm{SrMoO} / \mathrm{MgO}$ in the rest of the work.

\subsection{Chemical Characterization of the $\mathrm{SrMoO}_{4} / \mathrm{MgO}$ Fibers}

\subsubsection{X-ray Photoelectron Spectroscopy of the $\mathrm{SrMoO}_{4} / \mathrm{MgO}$ Fibers}

A comparative XPS analysis was completed on nano- $\mathrm{SrMoO}_{4}$ (Fig.2-a) and $\mathrm{SrMoO}_{4} / \mathrm{MgO}$ (Fig.2-b) synthesized using the same hydrothermal conditions. The main difference is that the nano-SrMoO 4 was synthesized without the inclusion of the $\mathrm{MgO}$ template/seed particles within the autoclave vessel. The deconvolution of the $\mathrm{O}, \mathrm{Sr}$ and Mo main photoelectron positions made it possible to quantify the chemical states, and concentration of the defects such as oxygen vacancies () and oxygen interstitials (). Deconvolution of the $\mathrm{O} 1 \mathrm{~s}$ position in $\mathrm{SrMoO}_{4} / \mathrm{MgO}$ proved that three chemical states of the oxygen exist in the material. Those are located at 530.11, 531.25 and $532.56 \mathrm{eV}$. The former value matches well with the literature values for lattice $\mathrm{O}^{2-}$ ion in $\mathrm{SrMoO}_{4}$ [35], while the latter agrees to the value reported for interstitial oxygen ions, and the last aligns with the values stated for chemisorbed oxygen $[36,37,38,39$, 
$40,41,42]$. The binding energy values reported here for the $\mathrm{O}^{2-}$ ion in $\mathrm{SrMoO}_{4} / \mathrm{MgO}$ are within $\sim 0.2 \mathrm{eV}$ proximity of the values measured for nano- $\mathrm{SrMoO}_{4}$. The corresponding full width at half maximum (FWHM) values for the lattice oxygen are 1.5 and $1.2 \mathrm{eV}$ for $\mathrm{SrMoO}_{4} / \mathrm{MgO}$ and nano-SrMoO 4 compound, respectively. The broad nature of the lattice component in the $\mathrm{MgO}$-modified material can be interpreted as the contribution of the incorporated $\mathrm{Mg}$. Approximately 57 at. $\%$ of $\mathrm{O}^{2-}$ ions were located on ordinary lattice positions, while 24 at. $\%$ of $\mathrm{O}^{2-}$ ions were located on interstitial sites, with the remaining 19 at $\%$ detected on chemi/physi-adsorbed locations. The significant increase in the fully-oxidized regular lattice sites, in addition to the decrease from 37 at.\% to 24 at.\% in the amount of interstitials, was observed in the $\mathrm{SrMoO}_{4} / \mathrm{MgO}$ in comparison to the nano-SrMoO . The effect of this will be explained later in the paper, when the electronic structure, including the band gap and work function of the material will be discussed.

The Mo 3d doublet is composed of the $\mathrm{Mo}^{5+}$ and $\mathrm{Mo}^{6+}$ peaks, which were positioned at 232.21 and $233.77 \mathrm{eV}$ for $\mathrm{SrMoO}_{4} / \mathrm{MgO}$. The broad feature of the $\mathrm{Mo}^{5+}$ and $\mathrm{Mo}^{6+}$ peaks, in comparison to the nano$\mathrm{SrMoO}_{4}$ compound, suggested complexity in the chemical environment of Mo. It was proven from the deconvolution that the as-synthesized $\mathrm{SrMoO}_{4} / \mathrm{MgO}$ contained $\sim 76$ at.\% $\mathrm{Mo}^{5+}$, while the nano- $\mathrm{SrMoO}_{4}$ contained 86.8 at. $\% \mathrm{Mo}^{5+}$. A similar increase in the $\mathrm{Mo}^{6+}$ was also observed; the amount of $\mathrm{Mo}^{6+}$ increased from 13 at.\% to 24 at.\%. The $\mathrm{Sr}^{2+}$ had well resolved spin-orbit components with the value of $1.76 \mathrm{eV}$ for $3 \mathrm{~d}_{5 / 2}$ and $3 \mathrm{~d}_{3 / 2}$, which is usual in stable compounds. However, in addition to the well-defined $3 \mathrm{~d}$ doublet, the shoulder formation was observed at the high energy side, which was fitted into another doublet that represents the $\mathrm{Mg}$ incorporated and/or effected areas in the host material. The deconvolution results indicated that $\sim 5$ at. $\%$ of the $\mathrm{Sr}$ was positioned in the $\mathrm{Mg}$ incorporated regions. The compositional depth profiling of the fired $\mathrm{SrMoO}_{4} / \mathrm{MgO}$ was obtained by XPS, and the profile is presented in Fig. 3. The most striking result of the analysis is that the atomic concentrations of the $\mathrm{Sr}, \mathrm{Mg}, \mathrm{O}$ and $\mathrm{Mo}$ do not vary through the thickness of the particles. In other words, the core $\mathrm{MgO}$ structure was totally lost during the reaction, even though the morphology of the $\mathrm{MgO}$ fibers remained. 
In order to envision this claim, $\mathrm{MgO}$ micro-fibers were treated in an aqueous solution (at a $\mathrm{pH}$ of 8 ) at ambient pressure conditions, and SEM micrographs of the overall microstructure is presented in Fig. 4. As discussed previously, $\mathrm{MgO}$ has significant solubility in aqueous solutions at both low and high $\mathrm{pH}$, so it was expected that a certain extent of dissolution of the seed particles was expected at the give reaction conditions. In order to synthesize the nano- $\mathrm{SrMoO}_{4}$ using the hydrothermal method, the $\mathrm{pH}$ was adjusted to $\sim 6$, which further increased during the reaction to 8 . At this $\mathrm{pH}$ level, the surface of the $\mathrm{MgO}$ core structure began to dissolve into the aqueous solution, while at the same time, the $\mathrm{SrMoO}_{4}$ phase was nucleating and precipitating onto the same surface. Interestingly, the dissolution reaction of the $\mathrm{MgO}$ did not disturb the nucleating process of the $\mathrm{SrMoO}_{4}$ and continued to serve as an active surface for nucleation and growth.

Fig. 5 represents the chemical state of the $\mathrm{Mg}$ throughout the probed depth of the $\mathrm{SrMoO}_{4}$ material. At the surface of the as-synthesized powder, the material contained $\mathrm{Mg}$ in three different chemical states, $\mathrm{MgO}, \mathrm{MgO}_{1-\mathrm{x}}$ and $\mathrm{Mg}(\mathrm{OH})_{2} . \mathrm{MgO}$ is strongly basic [43]; therefore, it was not surprising to identify $\mathrm{Mg}(\mathrm{OH})_{2}$. As can be observed from the graph, the relative amount of each chemical state of the $\mathrm{Mg}$ varies through the depth. After 1 min surface cleaning of the micro-fibers by $\mathrm{Ar}^{+}$ion etching, a shift in the $\mathrm{Mg}$ 2s photoelectron position occurred towards a lower binding energy that shows that $\operatorname{Mg}(\mathrm{OH})_{2}$ consisted of a few atomic layers. The shift was accompanied by an increase in the amount of $\mathrm{MgO}$ and $\mathrm{MgO}_{1-\mathrm{x}}$ phases. The shoulder formation and increase in the intensity at the high energy binding site indicates the relative amount of $\mathrm{MgO}_{1-\mathrm{x}}$ increase with the depth probed. The broad feature of the main peak itself suggests the potential formation of a $\mathrm{SrMg}_{\mathrm{x}} \mathrm{Mo}_{1-\mathrm{x}} \mathrm{O}_{4-\delta}$ solid-solution. The importance of the $\mathrm{MgO}_{1-\mathrm{x}}$ phases arises from the fact that the catalytic properties of the $\mathrm{MgO}$ are mainly dependent on the surface base sites; point defects, such as low coordinated $\mathrm{Mg}$ sites, facilitate the dissociative adsorption of $\mathrm{H}_{2}$ [44, 45]. It was not possible to conduct peak deconvolution analysis on both $\mathrm{Mg}$ and $\mathrm{O}$ peak positions in order to quantify the relative ratios of the $\mathrm{MgO}$ and $\mathrm{MgO}_{1-\mathrm{x}}$ phases due to fact that the amount of $\mathrm{Mg}$ was $\sim 2$ at $\%$. The low 
amount of material probed produced peaks with very low intensity which made it difficult to conduct peak deconvolution analysis.

In order to corroborate the XPS chemistry results, the bulk $\mathrm{SrMoO}_{4} / \mathrm{MgO}$ powder was analyzed by atomic adsorption spectroscopy (AAS). The AAS technique is known for its high accuracy for the quantitative determination of chemical elements, but the technique is known to lack the capability to measure chemical, structural and electronic structure of the material of interest. The technique is regarded as the best method for determining trace concentration of metals [46]; therefore, the technique was used in order to analyze the bulk amount of the $\mathrm{Mg}$ incorporated into the nano- $\mathrm{SrMoO}_{4}$ powder (which includes both substitutional and secondary phase precipitates). According to the AAS analysis of the $\mathrm{SrMoO}_{4} / \mathrm{MgO}$, the material contained $\sim 2$ at $\% \mathrm{Mg}$. The result is aligned with the XPS measurement regarding the amount of the $\mathrm{Mg}$ found in the modified compound.

\subsection{Structural Characterization of the $\mathrm{SrMoO}_{4} / \mathrm{MgO}$ Fibers}

XRD patterns of the calcined nano- $\mathrm{SrMoO}_{4}$ and $\mathrm{SrMoO}_{4} / \mathrm{MgO}$ are presented in Fig. 6. All of the diffraction peaks can be indexed with the ICSD card \#01-085-0586 for the nano-SrMoO 4 and $\mathrm{SrMoO}_{4} / \mathrm{MgO}$. The XRD measurements were taken from the samples after calcination at $1000^{\circ} \mathrm{C}$ for $5 \mathrm{~h}$. The calcined samples were thought to be a better representation of the final sensing material, since these materials were fired to this temperature to adhere to the metal electrode and substrate. The sharp and high intensity diffraction peaks of the calcined powders showed a good level of crystallinity with no secondary phases, such as $\mathrm{MoO}_{3}$ and/or $\mathrm{SrO}$ present. Both materials showed the tetragonal scheelite structure. The scheelite structure contains four formula units per unit cell with four $\mathrm{Sr}^{2+}$ and four $\left(\mathrm{MoO}_{4}\right)^{2-}$ ions. The $\mathrm{Mg}(\mathrm{OH})_{2}$ peak was assigned in accordance to the ICSD card \#01-075-1527. However, it was not possible to identify the (001), (101) and (102) main diffraction peaks due to the low intensity and strong positional match with the main $\mathrm{SrMoO}_{4}$ peaks. An increase of the relative intensity of the (101), (211) and (116) peaks for the $\mathrm{SrMoO}_{4}$ was observed due to potential contribution from the (001), (101) and (102) of $\mathrm{Mg}(\mathrm{OH})_{2}$. 
The inset figures within Fig. 6 provide a better visualization regarding the difference in both the XRD spectra. Further inspection of both spectra showed that the $\mathrm{SrMoO}_{4} / \mathrm{MgO}$ displayed different diffraction characteristics near the $2 \theta$ value of $64^{\circ}$. This peak position corresponds to the (111) plane of the $\mathrm{Mg}(\mathrm{OH})_{2}$. It was expected to observe the hydrated $\mathrm{Mg}$ compound due to its tendency to form in the presence of steam even at room temperature. Therefore, it is normal to observe the $\operatorname{Mg}(\mathrm{OH})_{2}$ peak even after high temperature heat treatment. The XRD spectra showed no other phase formation, neither SrO or the double-perovskite $\mathrm{Sr}_{2} \mathrm{MgMoO}_{6}$, was detected. In addition, the FWHM values for both powders contrasted by more than $5 \%$. The most striking points of the XRD data are the existence of the $\operatorname{Mg}(\mathrm{OH})_{2}$ phase in the $\mathrm{SrMoO}_{4} / \mathrm{MgO}$, in addition to the well-resolved peak shifts. There is a regular shift of all the $\mathrm{SrMoO}_{4} / \mathrm{MgO}$ peaks towards the higher $2 \theta$ values by $0.3^{\circ}$ compared to that identified for the nano$\mathrm{SrMoO}_{4}$. This could be attributed to the relatively higher amount of the $\mathrm{Mo}^{6+}$ in the modified structure in comparison to the pure $\mathrm{SrMoO}_{4}$, as the former had 24 at.\% $\mathrm{Mo}^{6+}$ while the latter possessed just 13 at.\%.

\subsection{Electronic Characterization of the $\mathrm{SrMoO}_{4} / \mathrm{MgO}$ Fibers}

The consequences of the $\mathrm{Mg}$ incorporation can be observed in the electronic characteristics of the material. The work function and band-gap for the nano- $\mathrm{SrMoO}_{4}$ and $\mathrm{SrMoO}_{4} / \mathrm{MgO}$ were measured via ultraviolet photoelectron spectroscopy (UPS) and ultraviolet-visible light absorption spectrum (UV-Vis),

respectively. The differences in the electronic structure of the nano- $\mathrm{SrMoO}_{4}$ and $\mathrm{SrMoO}_{4} / \mathrm{MgO}$ were observed both in the band-gap and work function values. The UPS measurements were completed using $25.4 \mathrm{eV}$ UV-rays produced through the ionization of a He source. The activation energy calculations were conducted to quantify the grain boundary Schottky barrier height in both the nano-SrMoO 4 and $\mathrm{SrMoO}_{4} / \mathrm{MgO}$ materials.

\subsubsection{Work Function () Measurement}

In order for the sensing material to serve its function, the material surface must show a high affinity for the redox reaction with the gas phase, which includes ample ability to exchange charge (electrons and/or ions) with the gaseous species. In addition,- and the sensing material must show adequate ability to 
transfer electrons to the sensor electrode. Therefore, the work function () plays an important role in the overall sensing process, since both of these mechanisms are affected by this value. The is the energy that is required to remove an electron from the Fermi level to vacuum in semiconductors. The definition differs slightly for metals due to fact that Fermi level oceurs in the conduction band. The is not a characteristic property of a bulk material, but rather a distinctive feature of the material surface, which depends on the surface's crystal facet and stoichiometry. The difference in the values for $\mathrm{SrMoO}_{4}$ and $\mathrm{SrMoO}_{4} / \mathrm{MgO}$ are based on the shift of the Fermi level, as well as, the location of the bottom edge of the Fermi level. The interface between semi-conducting oxides and metals create a Schottky contact due to the discrepancy in the work functions. Platinum metal-oxide interfaces are known to display a Schottky contact rather than anmic contact at high temperature $[47,48]$. There are two Schottky barriers in a resistive-type sensor composed of a particulate sensing material. The first Schottky barrier occurs among the sensing material grains. The second is observed between the sensing material and the sensor electrode (intereonnect). The Schottky barriers among the grains will be explored in the following section.

The work function measurements were completed for nano-SrMøO${ }_{4}$, micron-size $\mathrm{SrMoO}_{4}$, and the $\mathrm{SrMoO}_{4} \mathrm{MgO}$ material. The measured values were 9.3, 8.2 and $7.7 \mathrm{eV}$ for the nano-SrMoO 4 , micron$\mathrm{SrMoO}_{4}$ and $\mathrm{SrMoO}_{4} / \mathrm{MgO}$, respectively. The micron-size $\mathrm{SrMoO}_{4}$ was included in order to better distinguish the effect of the $\mathrm{MgO}$ and the effect of the $\mathrm{SrMoO}_{4}$ particle size on the work function (). The reported for platinum $(\mathrm{Pt})$ is $5.7 \mathrm{eV}$, which was the interconnect material used in this sensor work [49]. When a semi-conducting oxide and Pt come into contact, the Fermi level will be adjusted due to thermodynamic necessity. The $\mathrm{e}^{-}$will experience an energy barrier (), whose height for an n-type semiconducting oxide can be derived from the difference between the work function of the metal and electron affinity $(\chi)$ of the semiconductor. The electron affinity, typically denoted by $\boldsymbol{E}_{\boldsymbol{E} A}$ or $\chi$, is defined by the amount of energy attained by placing an electron from vacuum to the bottom of the conduction band of the semiconductor. The analogy will be altered at a temperature higher than absolute zero, with the effect of doping and/or non-stoichiometry, since an $\mathrm{e}^{-}$will go to the Fermi level as illustrated in Fig. 7. 
Therefore, the work function values measured were considered analogous to the electron affinity of the semiconductors, as described in Eq. 2 and 3. Eq. 4 presents the equation for the Schottky barrier height based on the difference between the work functions of the materials at the interface.

\section{Eq. 2}

Eq. 3

Eq. 4

Generally, a low work function is desired in order to promote the transport of electrons to the sensor electrode or interconnect. The magnitude of for nano-SrMoO 4 , micron- $\mathrm{SrMoO}_{4}$-micron and $\mathrm{SrMoO}_{4} / \mathrm{MgO}$ was calculated as $3.6 \mathrm{eV}, 2.5 \mathrm{eV}$ and $2.0 \mathrm{eV}$, respectively. The lowest barrier height was measured for $\mathrm{SrMoO}_{4} / \mathrm{MgO}$.

\subsubsection{Band Gap Measurements}

The UV-Vis absorption spectrum of the nano- $\mathrm{SrMoO}_{4}$ and $\mathrm{SrMoO}_{4} / \mathrm{MgO}$ are presented in Fig. 8. The formula proposed by Wood et al. [50] was used to estimate the optical bandgap from the UV-Vis spectrum [51]. Both the shape and the value obtained by interpolating the linear part of the graph are of significant importance to this work. The measured values for the band-gap were 3.7 and $3.2 \mathrm{eV}$ for nano$\mathrm{SrMoO}_{4}$ and $\mathrm{SrMoO}_{4} / \mathrm{MgO}$, respectively. The band gap value for the nano- $\mathrm{SrMoO}_{4}$ was a good match with the values reported in literature, especially when considering the non-stoichiometry of the material $[52,53,54,55]$. Despite the $0.5 \mathrm{eV}$ decrease in the bandgap, the insulator/semiconductor transition temperature for nano- $\mathrm{SrMoO}_{4}$ was $475^{\circ} \mathrm{C}$, while a transition temperature of $600^{\circ} \mathrm{C}$ was observed for $\mathrm{SrMoO}_{4} \mathrm{MgO}$. The electrical resistance value for both materials was $2 \mathrm{M} \Omega$ at $1000^{\circ} \mathrm{C}$.

The significant red shift in the $\mathrm{SrMoO}_{4} / \mathrm{MgO}$ spectra can be attributed to many factors including, order/disorder, morphology, stoichiometry, oxidation state, secondary phases, defect type (and density), grain size and shape. The absorption spectrum of the $\mathrm{SrMoO}_{4} / \mathrm{MgO}$ displays the typical optical behavior for a wide bandgap n-type semiconductor; however, it should be noted that it slightly deviates from the 
regular trend at the higher energy section. The section of interest is highlighted by the green circular shaded region in the $\mathrm{SrMoO}_{4} / \mathrm{MgO}$ and indicated with the square shaded region for the nano- $\mathrm{SrMoO}_{4}$. This deviation is due to the residual $\mathrm{MgO}$ that continues adsorption instead of presenting a smooth plateau of absorption as observed in nano- $\mathrm{SrMoO}_{4}$. It is obvious that there is no observable band edge for the $\mathrm{SrMoO}_{4} / \mathrm{MgO}$ composition, as can be seen for the nano- $\mathrm{SrMoO}_{4}$ (presented in the inset figure). The continuous absorption clearly indicates that there is interference from a high band gap material, such as that from $\mathrm{MgO}$ which has a band gap of $7.8 \mathrm{eV}$ [56]. The reduction in the $\mathrm{SrMoO}_{4} / \mathrm{MgO}$ band gap can be attributed to cation or anion defects within the structure. Anion defects would primarily align with the oxygen vacancy and interstitial oxygen ion concentration. The amount of interstitial oxygen ions in $\mathrm{SrMoO}_{4} / \mathrm{MgO}$ are lower than that of nano- $\mathrm{SrMoO}_{4}$, which was shown in the XPS data in the previous section. In the case of cation defects, alterations in the B-site composition may be attributed to Mo deficiency, a change in the overall oxidation state (during the hydrothermal growth), or the substitution of the $\mathrm{Mg}$ into the lattice that would potentially lead to impurity level bands in the main bandgap. Other reports in literature confirm the reduction of the band gap by doping with a lower valance ion, such as the following doped-oxide systems: $\mathrm{Er}^{3+}: \mathrm{CeO}_{2}, \mathrm{Ga}^{3+}: \mathrm{TiO}_{2}$, and $\mathrm{Ga}^{3+}: \mathrm{WO}_{3}[57,58,59]$.

\subsubsection{Activation Energy Calculations for $\mathrm{SrMoO}_{4} / \mathrm{MgO}$ Grain Boundary Schottky Barrier}

\section{Height}

The total electronic resistance in the $\mathrm{SrMoO}_{4} / \mathrm{MgO}$ is governed by both the resistance of the bulk grains and grain boundaries. For most semi-conducting oxides, the grain boundaries dominate the total resistance of the material due the presence of second-phases and other defect-association along the grain boundaries. These two contributors usually form a space-charge layer (sometimes termed depletion layer) between the grains, resulting in a Schottky barrier which limits both electronic and ionic conduction. The influence of this barrier can be correlated to the relative thickness of the depletion layer (compared to the average size of the grains) and the Schottky barrier height. Due to the larger $\mathrm{SrMoO}_{4} / \mathrm{MgO}$ grain size, it is assumed that the bulk grain conductivity was unaltered by the depletion layer (due to its nano-size 
thickness in comparison to the large grain size); this means that the bulk grain conductivity was not dominated by the influence of the depletion layer and retained its semi-conducting nature. Regardless, it is assumed that the absolute sensor resistance was dominated by the grain boundary resistance (governed by the depletion layer), as typical of semi-conducting oxides.

In this work, it is assumed that the grain boundary Schottky barrier () formation was the result of both the grain boundary defects and surface adsorbed oxygen ions. Activation energy calculations were carried out in order to quantify the barrier height for . It must be restated here that this is the second-type of Schottky barrier discussed in this work; the first-type of Schottky barrier was discussed in the previous sections, and both schematically represented in Fig. 7. The magnitude of the Schottky barrier () can be assessed from the formula presented in Eq. 5.

\section{Eq. 5}

The Arrhenius formula presented by Schierbaum et al. was used in this work which links the activation process for electron transport to electrical conductance $(\boldsymbol{G})$, or electrical resistance $(\boldsymbol{R})$ [60]. Fig. 9 shows the natural logarithm of the linear fit of the sensor resistance versus $\left(\mathrm{k}_{\mathrm{B}} \mathrm{T}\right)^{-1}$ for nano-SrMoO 4 and $\mathrm{SrMoO}_{4} / \mathrm{MgO}$. The resistances of both nano-SrMoO 4 and $\mathrm{SrMoO}_{4} / \mathrm{MgO}$ were both measured in $1 \% \mathrm{O}_{2}+\mathrm{N}_{2}$ atmosphere on the same sensor platform with a current load of 5-10 $\mu$ A DC. By taking the slope of the $\ln (\mathrm{R})$ vs $\left(\mathrm{k}_{\mathrm{B}} \mathrm{T}\right)^{-1}$ plot, it was possible to calculate the activation energy $\left(\boldsymbol{E}_{\mathrm{A}}\right)$ values for both materials. In Eq.5, the $\boldsymbol{E}_{\boldsymbol{A}}$ denotes the energy to form and transfer the electron through the material, $T$ represents absolute temperature, and $k_{B}$ is the Boltzmann constant, while $P$ and $\sigma$ are the proportionality constant and bulk conductivity, respectively.

The $\boldsymbol{E}_{\boldsymbol{A}}$ values calculated for nano- $\mathrm{SrMoO}_{4}$ and $\mathrm{SrMoO}_{4} / \mathrm{MgO}$ were 1.63 and $1.48 \mathrm{eV}$, respectively. Both values are higher than the $1.34 \mathrm{eV}$ reported for $\mathrm{SrMoO}_{4}$ in the literature [61]. However, the value reported in for $\mathrm{SrMoO}_{4}$ was tested in atmospheric conditions in the form of a pressed pellet. The typical microstructure of a high-temperature sintered, polycrystalline $\mathrm{SrMoO}_{4}$ ceramic would potentially possess a low level of intergranular porosity; in addition, the higher firing would result in grains and grain 
boundaries with higher order and a different defect state. The Schottky barriers among the grains stem from the space charge layer which exist due to the existence of interstitial oxygen ions [62], thus testing in high oxygen background environment will also decrease the overall activation energy. The grain size and number of grain boundaries may also have an influence on the overall resistivity of the bulk material. The nano- $\mathrm{SrMoO}_{4}$ and $\mathrm{SrMoO}_{4} / \mathrm{MgO}$ both experienced coarsening beginning at $\sim 600^{\circ} \mathrm{C}$ and both materials ended with a similar grain size. Therefore, it may be assumed that the grain size did not influence the $\boldsymbol{E}_{\boldsymbol{A}}$ significantly for both the nano- $\mathrm{SrMoO}_{4}$ and $\mathrm{SrMoO}_{4} / \mathrm{MgO}$ materials.

\section{Sensor Testing of $\mathrm{SrMoO}_{4} / \mathrm{MgO}$ for Hydrogen $\left(\mathrm{H}_{2}\right)$}

The $\mathrm{H}_{2}$ sensing experiments were completed in accordance with the testing procedure described previously in the experimental section. Fig. 10-a presents the time dependent relative resistance change curves $(R)$ for the testing of the $\mathrm{SrMoO}_{4} / \mathrm{MgO}$ sensor material in $\mathrm{H}_{2}$ at 600,800 and $1000^{\circ} \mathrm{C}$ under $1 \% \mathrm{O}_{2}$ balanced with $\mathrm{N}_{2}$. The material showed a rapid and intense sensor response against $\mathrm{H}_{2}$ at all temperatures tested. The response was n-type in nature to all target gas concentration levels, testing temperatures and different oxygen background concentrations. The probable sensing reaction is shown in Eq. 6, where the dissociated $\mathrm{H}_{2}$ reacts with lattice and/or interstitial oxygen ions leading to the formation of $\mathrm{H}_{2} \mathrm{O}$. As previously discussed, it is believed that the available second-phase $\mathrm{MgO}$ facilitated the adsorption and dissociation of the $\mathrm{H}_{2}$.

\section{[Eq. 6]}

The $R_{\max }$ values of $-25,-27$, and -30 were measured upon exposure to the 20 min pulses of 1000,2000 and $4000 \mathrm{ppm}$ of $\mathrm{H}_{2}$ at $600^{\circ} \mathrm{C}$. The $\mathrm{SrMoO}_{4} / \mathrm{MgO}$ displayed a smooth and repeatable response to the $5 \mathrm{~min}$ pulses of $\mathrm{H}_{2}$ at the same temperature. The $R_{\max }$ values for the 5 min pulses of $1000,2000,4000 \mathrm{ppm}$ of $\mathrm{H}_{2}$ were $-24,-26$, and -29 , respectively. The same values were also recorded for the 2000 and $1000 \mathrm{ppm}$ exposures after receiving the maximum concentration. The sensor also detected the $4000 \mathrm{ppm}_{2}$ concentration for the 30 and $15 \mathrm{~s}$ pulses; the $R_{\max }$ values were -19 and -9.5 , respectively. The time dependent relative resistance change curve of the $\mathrm{SrMoO}_{4} / \mathrm{MgO}$ at $800^{\circ} \mathrm{C}$ is presented in the Fig. 10-b. At 
$800^{\circ} \mathrm{C}$, there was a jump in the response for the $\mathrm{SrMoO}_{4} / \mathrm{MgO}$ in comparison to that measured at $600^{\circ} \mathrm{C}$. The sensor response was smooth and drift-free. The $R_{\max }$ values were $-66,-79$ and -85 for the $20 \mathrm{~min}$ exposure of 1000,2000 and $4000 \mathrm{ppm}_{2}$ at $800^{\circ} \mathrm{C}$, respectively. The $R_{\max }$ values for 5 min pulses of 1000, 2000 and $4000 \mathrm{ppm}_{2}$ were -46 , -64 and -75, respectively. At this temperature, the $\mathrm{SrMoO}_{4} / \mathrm{MgO}$ detected the 30 and $15 \mathrm{~s}$ exposures of $4000 \mathrm{ppm} \mathrm{H}_{2}$ with the $R_{\max }$ values of -19.2 and -6.5 , respectively.

Fig. 10-c shows the time dependent relative resistance change curve for the $\mathrm{SrMoO}_{4} / \mathrm{MgO}$ at $1000^{\circ} \mathrm{C}$.

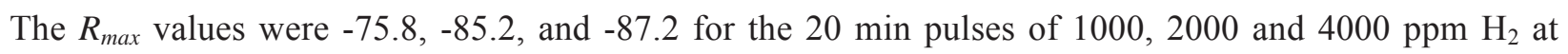
$1000^{\circ} \mathrm{C}$, respectively. The same trend was valid for the $5 \mathrm{~min}$ pulses and the $R_{\max }$ values were $-59.5,-67.8$ and -73.7 , respectively. In the case of 30 and $15 \mathrm{~s}$ pulses, the $R_{\max }$ were -46.7 and -26.5 for $4000 \mathrm{ppm}$ of $\mathrm{H}_{2}$. The material showed very high sensitivity and excellent repeatability upon multiple exposures in one sensing cycle. The recorded response times for the $\mathrm{SrMoO}_{4} / \mathrm{MgO}$ against the 20 min exposure of 4000 ppm $\mathrm{H}_{2}$ were $6.1,12.6$ and $8.4 \mathrm{~min}$ at $600^{\circ} \mathrm{C}, 800^{\circ} \mathrm{C}$ and $1000^{\circ} \mathrm{C}$, respectively. The $\mathrm{SrMoO} / \mathrm{MgO}$ not only revealed high sensor response, repeatability, and relatively high response kinetics, but also it showed the ability to differentiate between the different concentration levels of the target gas. At $1000^{\circ} \mathrm{C}$, the $R_{\max }$ was -87.2 and the sensor displayed a similar high response even after successive tests and subsequent $\mathrm{H}_{2}$ exposures that covered almost $150 \mathrm{~h}$ of operation at $1000^{\circ} \mathrm{C}$. These discussed results are one of the few successful demonstrations reported in literature of a resistive-type hydrogen sensor that operates at such an elevated temperature regime. The high sensor response of the $\mathrm{SrMoO}_{4} / \mathrm{MgO}$ material towards $\mathrm{H}_{2}$ can be explained on the basis of three distinct characteristics. These characteristics may be attributed to the porous/tailored microstructure, the catalytic activity towards $\mathrm{H}_{2}$ dissociation/adsorption, and the electronic modification of the $\mathrm{SrMoO}_{4}$. The electronic modification and porous microstructure effects for the $\mathrm{SrMoO}_{4}$ sensing material was explored in the previous sections. The catalytic modification will be explored in the next main section.

\subsection{Cross-Selectivity Testing}




\subsubsection{Carbon Monoxide (CO) Testing}

Carbon monoxide $(\mathrm{CO})$ is another common reducing gas that many times causes significant interference to specific hydrogen sensing, since a portion of the surface redox reaction may be related to the oxidation of $\mathrm{CO}$ as well as $\mathrm{H}_{2}$. $\mathrm{CO}$ is a common product of many industrial processes, where $\mathrm{H}_{2}$ and $\mathrm{CO}$ coexist within the gas stream. The $\mathrm{CO}$ cross-selectivity testing of the $\mathrm{SrMoO}_{4} / \mathrm{MgO}$ material was completed for three different temperature regimes $\left(600,800\right.$ and $\left.1000^{\circ} \mathrm{C}\right)$ in accordance with the testing procedure described previously for $\mathrm{H}_{2}$. Fig. 11 represents maximum relative resistance change for 4000 ppm of $\mathrm{CO}$ at $1000^{\circ} \mathrm{C}$. The $\mathrm{CO}$ sensing results presented here are very similar to data presented in our previous work that focuses on the nano- $\mathrm{SrMoO}_{4}[16]$. The relative resistance change curve was not included, since the material showed insignificant and inconsistent sensor response to $\mathrm{CO}$ at all temperatures tested. The material showed the typical n-type response with $R_{\max }$ values less than -2 . Only the longer 20 min $\mathrm{CO}$ exposures at a level of $4000 \mathrm{ppm}$ showed a reading level that could be detected. The $R_{\max }$ values for $\mathrm{CO}$ at 800 and $1000^{\circ} \mathrm{C}$ was -3.1 and -2.5 , respectively, for a concentration of 4000 ppm CO. This level of response is far below that measured for the $\mathrm{H}_{2}$ values detected at the same temperature; this indicates that the cross-selectivity is relatively low for this gas mixture. The reason for this low response is still being investigated, but it is known that $\mathrm{MgO}$ is a weak adsorber of $\mathrm{CO}[63,64]$. It should be kept in mind that at $>600^{\circ} \mathrm{C}$, stable $\mathrm{CO}$ adsorption and carbonate formation is not favorable. In addition, it is not expected that $\mathrm{MgCO}_{3}$ formed either since this composition decomposes at $350^{\circ} \mathrm{C}[65$, 66]. In the end, the $\mathrm{MgO}$ may have an effect of further reducing the $\mathrm{CO}$ oxidation, and it may be assumed that any $\mathrm{CO}$ oxidation is primarily associated with its reaction with the $\mathrm{SrMoO}_{4}$ surface.

\subsubsection{Sulfur dioxide $\left(\mathrm{SO}_{2}\right)$ Testing}

Selectivity against sulfur species is of particular interest for $\mathrm{H}_{2}$ sensing since many reforming processes of fossil fuels, where the high-temperature sensors would be used, contain significant levels of sulfur. In the case of sulfur compound exposure, $\mathrm{MgO}$ can form a $\mathrm{MgS} / \mathrm{MgSO}_{4}$ product, which would be expected to cover the surface of the sensing material and potentially inhibit further reaction/interaction 
with the active sensing layer. It was also perceived that the $\mathrm{MgO}$ additions could also lead to substitution into the $\mathrm{SrMoO}_{4}$ structure (onto the Mo site) after high-temperature processing (and potentially during operation). The solid solution formation would lead to the modification of the electronic properties as well as the defect chemistry on the surface.

In many fossil fuels, there is a high level of sulfur species which exist or transform into $\mathrm{SO}_{2}$ and $\mathrm{H}_{2} \mathrm{~S}$ during gasification or combustion. These compositions complicate the stability of many catalyst and fuel cell components. In previous publications by the current authors, the team investigated the use of $\mathrm{SrMoO}_{4}$, and other molybdate and tungstate compositions, for high temperature sulfur species sensing [16]. The $\mathrm{SrMoO}_{4}$ composition was shown to have significant sensitivity to sulfur species (both $\mathrm{SO}_{2}$ and $\mathrm{H}_{2} \mathrm{~S}$ ), but very low sensitivity to $\mathrm{H}_{2}$ (as described in this paper also) [16]. The current paper demonstrated that the incorporation of the $\mathrm{MgO}$ into the $\mathrm{SrMoO}_{4}$ lattice, and as a second phase into the bulk material, resulted in a drastic increase in sensitivity to $\mathrm{H}_{2}$. Also, the synthesis method used to produce this complex composite not only altered the chemistry, but also resulted in a change in the electronic nature of the resultant $\mathrm{SrMoO}_{4}$. In order to better understand the full effect of this change, $\mathrm{SO}_{2}$ testing was also completed on the $\mathrm{SrMoO}_{4} / \mathrm{MgO}$ material to quantify the cross-selectivity. Fig. 11 shows the maximum resistance change $\left(R_{\max }\right)$ values of $\mathrm{SrMoO}_{4} / \mathrm{MgO}$ for $\mathrm{SO}_{2}$ at 600,800 and $1000^{\circ} \mathrm{C}$ together with the $R_{\max }$ values measured for $\mathrm{H}_{2}$ and $\mathrm{CO}$ for comparison purposes. Interestingly, $\mathrm{SrMoO}_{4} / \mathrm{MgO}$ showed a regular n-type semi-conducting sensor behavior with very low sensor response towards $\mathrm{SO}_{2}$ at all of the testing temperatures. The response seen in this work is far different from that measured previously for the pure nano- $-\mathrm{SrMoO}_{4}[16]$.

The $R_{\max }$ values for the $\mathrm{SrMoO}_{4} / \mathrm{MgO}$ were $-2.8,-3.7$ and -5.9 upon exposure to the 20 min pulses of 500,1000 and $2000 \mathrm{ppm}$ of $\mathrm{SO}_{2}$ at $600^{\circ} \mathrm{C}$. It should be noted that sensor did not detect the first $500 \mathrm{ppm}$ $\mathrm{SO}_{2}$ exposure, and surprisingly, the first detection of $1000 \mathrm{ppm} \mathrm{SO}_{2}$ was higher in sensitivity compared to the $2000 \mathrm{ppm}$ level. At $600^{\circ} \mathrm{C}$, the $R_{\max }$ for the $5 \mathrm{~min}$ pulses of $500,1000,2000 \mathrm{ppm}$ of $\mathrm{SO}_{2}$ were -2.0 , $5.5,-3.1$, respectively. Despite the low response, the sensor detected the $2000 \mathrm{ppm} \mathrm{SO}_{2}$ at the $30 \mathrm{~s}$ 
exposure, with the $R_{\max }$ value of -2 . The sensor could not detect the $\mathrm{SO}_{2}$ at the $5 \mathrm{~s}$ and $15 \mathrm{~s}$ pulses. For the

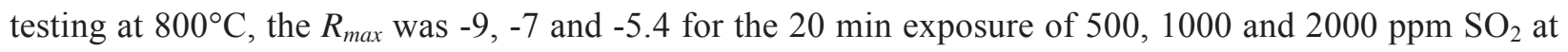
$800^{\circ} \mathrm{C}$, respectively. It is noteworthy to indicate that despite the increase in the concentration of the $\mathrm{SO}_{2}$, the sensor response decreased after each exposure. This is potentially due to the poisoning of the active sensing area. This lower response, and its cause, will be addressed in the next subsection in detail. The same trend was observed for the 5 min pulses, as the $R_{\max }$ values were $-6,-7$ and -8 for 500,1000 and $2000 \mathrm{ppm}$ of $\mathrm{SO}_{2}$, respectively. The $\mathrm{SrMoO}_{4} \mathrm{MgO}$ detected the 30 and $15 \mathrm{~s}$ exposures of $2000 \mathrm{ppm} \mathrm{SO}_{2}$ with the $R_{\max }$ of -5 and -3 , respectively. For $1000^{\circ} \mathrm{C}$, the $R_{\max }$ for the first response was as high as -50.5 for $500 \mathrm{ppm}$ of $\mathrm{SO}_{2}$; however, the $R_{\max }$ values for 1000 and 2000 ppm of $\mathrm{SO}_{2}$ were -7 and -12.5 , respectively. The rest of the exposures were not detected apart from the $5 \mathrm{~min}$ exposure for $500 \mathrm{ppm}$, in addition to the 30 and 15 s pulses. The $R_{\max }$ in those cases were $-13,-11$ and -7 .

The reason behind the lower sensitivity toward $\mathrm{SO}_{2}$ can be explained on the basis of the compound formation between $\mathrm{MgO}$ and $\mathrm{SO}_{2}$, which is termed as poisoning in sensor/catalysis literature [67]. It is well known that $\mathrm{MgO}$ destructively adsorbs sulfur dioxide [68, 69, 70, 67], and other catalyst poisons such as hydrogen halides, organochloride [71], and organophosphorus [72] [73, 74, 75]. The proposed sensing mechanism for $\mathrm{SO}_{2}$ is aligned with previous studies, where the $\mathrm{SO}_{2}$ interacts with the interstitial and/or lattice oxide and attaches weakly to the surface [16]. Eq.7-13 illustrate a few of the potential reactions for molecular oxygen adsorption to the surface and further dissociation and incorporation into interstitial and/or lattice sites. The chemisorption of $\mathrm{SO}_{2}$ onto a perfect $\mathrm{MgO}$ surface is relatively weak; however, in the case of a non-stoichiometric surface with surface defect sites, sulfite formation may occur strongly.

\section{[Eq.7]}

[Eq.8]

[Eq.9]

[Eq. 10] 


\section{[Eq. 11]}

\section{[Eq. 12]}

\section{[Eq. 13]}

Eq. 14-17 represent a few of the various potential oxidation reactions that may occur for $\mathrm{SO}_{2}$ forming $\mathrm{SO}_{3}$ (and potential further formation of sulfite and sulfate ions). This interaction may be enhanced due to the interaction of $\mathrm{O}$ ions with $\mathrm{SO}_{2}$ on surface defects, such as the four-coordinated $\mathrm{Mg}^{2+}$ sites [76]. A single $\mathrm{SO}_{2}$ molecule favors the interaction with the $\mathrm{MgO}$ (100) surface where the two oxygen ions are bridging two neighboring $\mathrm{Mg}^{2+}$ positions. In other words, the $\mathrm{SO}_{2}$ adsorbs molecularly at the fivecoordinated $\mathrm{Mg}^{2+}$ cation sites [77]. In another interaction, it may be assumed that the $\mathrm{SO}_{2}$ weakly bonds to the surface and interacts with the interstitial oxygen ions, which creates $\mathrm{SO}_{3}$ that further oxidizes to $\mathrm{SO}_{4}$, and/or stabilizes itself by reducing $\mathrm{MgO}$ to form $\mathrm{MgSO}_{4}$. In this case, the $\mathrm{MgO}$ particulate surface would be saturated with magnesium sulfate $\left(\mathrm{MgSO}_{4}\right)$ [67]. Previous work has shown that the reaction of $\mathrm{SO}_{2}$ with $\mathrm{MgO}$ is favorable to form $\mathrm{MgSO}_{4}$ as low as $700^{\circ} \mathrm{C}[78,67]$, where the standard enthalpies of formation $\left(\Delta \mathrm{H}_{\mathrm{f}}{ }^{\mathrm{o}}\right)$ for $\mathrm{MgO}$ and $\mathrm{Mg}\left(\mathrm{SO}_{4}\right)$ are -603.6 and $-1278.2 \mathrm{~kJ} / \mathrm{mol}$, respectively. The $\mathrm{MgSO}_{4}$ is a stable compund, with a decomposition temperature of $1135^{\circ} \mathrm{C}$ [79]. If the testing atmosphere changes from pure $\mathrm{N}_{2}$ to $\mathrm{O}_{2}$ containing atmosphere, then the decompsition products would contain more $\mathrm{SO}_{3}[80]$. Catalyst literature also reported sulfate, sulfite and sulfide formation with $\mathrm{MgO}$ near and beyond $500^{\circ} \mathrm{C}$ $[81,67]$. It was reported by Lee et al. that the exposure of $\mathrm{MgO}$ to $\mathrm{SO}_{2}$, which was completed in order to promote the $\mathrm{SO}_{2}$ transformation to $\mathrm{SO}_{3}$, resulted in the formation of a compound of $\mathrm{Mg}$ and $\mathrm{S}\left(\mathrm{MgSO}_{4}\right)$ [82]. The same authors also reported that after exposure of $\mathrm{MgO}$ to $\mathrm{SO}_{2}$ at $>500^{\circ} \mathrm{C}, \mathrm{MgO}$ could not recover to its initial state [83].

\section{[Eq. 14]}

[Eq. 15]

[Eq. 16]

[Eq. 17] 
For the given work, it is asumed that the sulfur oxidation reaction occurs with local surface oxygen ions (or with the interstitial oxygen ions residing within the $\mathrm{SrMoO}_{4}$ structure). The oxidation process liberates electrons that alters the resistance of the sensing material. In the case of the $\mathrm{SrMoO}_{4} / \mathrm{MgO}$, it appears that after the initial surface covarage of the $\mathrm{SO}_{2}$, a limiting point is reached where the sensor response is greatly reduced with further exposure due to poisoning of the surface. A few of the multiple reaction steps leading to the sulfide/sulfate formation are presented in Eq. 18-21. The conversion of the magnesium sulfite $\left(\mathrm{MgSO}_{3}\right)$ composition to $\mathrm{MgSO}_{4}$ is also possible at this temperature due to the availability of interstitial oxygen ions from the $\mathrm{SrMoO}_{4} / \mathrm{MgO}$ sensing material [67]. However, as can be seen from Fig. 11, it is obvious that sensor response still exists towards $\mathrm{SO}_{2}$ due to insufficient coverage of the surface of the $\mathrm{SrMoO}_{4}$ by $\mathrm{MgO}$, although the $R_{\max }$ values are in the range of -10 .

\section{[Eq. 18]}

\section{[Eq. 19]}

\section{[Eq. 20]}

[Eq. 21]

It is interesting to note that the sensor regained its functionality quickly after removing the $\mathrm{SO}_{2}$ and switching back to regular $\mathrm{H}_{2}$ containing testing environment. One potential reason for this response may be due to $\mathrm{H}_{2}$ cleaning of the potential poisoned surface, due to the reducing nature of the $\mathrm{H}_{2}$ against $\mathrm{Mg}\left(\mathrm{SO}_{4}\right)$ [84]. Ding et al. showed that the existence of $\mathrm{H}_{2} \mathrm{O}$ accelerates the decomposition of $\mathrm{MgSO}_{4}$ under $\mathrm{H}_{2}$ atmosphere [85]; therefore, the sensor used for full-scale $\mathrm{SO}_{2}$ tests managed to exhibit the usual $\mathrm{H}_{2}$ sensing performance during successive tests switching from $\mathrm{SO}_{2}$ to $\mathrm{H}_{2}$ and vice versa. The sulfur poisoning could be removed from the sensor during exposure by high concentrations of $\mathrm{H}_{2}$, or the presence of $\mathrm{H}_{2}$ may limit the formation of the sulfate/sulfite composition during operation when a finite amount of $\mathrm{H}_{2}$ is present. This feature demonstrates the selective sensing capability of the $\mathrm{SrMoO}_{4} / \mathrm{MgO}$ fibers when exposed to levels of $\mathrm{SO}_{2}$ at high temperature. 


\subsubsection{XPS Characterization of $\mathrm{SrMoO}_{4} / \mathrm{MgO}$ after $\mathrm{SO}_{2}$ Exposure}

The low sensitivity of $\mathrm{SrMoO}_{4} / \mathrm{MgO}$ towards $\mathrm{SO}_{2}$ was further investigated by XPS analysis. The XPS spectrum of the $\mathrm{SrMoO}_{4} / \mathrm{MgO}$ sensor material after $\mathrm{SO}_{2}$ testing is presented in Fig. 12. In comparison to the as-synthesized conditions, oxygen exhibited two separate peaks due to the relatively large difference in the binding energy of $\mathrm{O}^{2-}$ in oxides $\left(\mathrm{MgO}, \mathrm{SrMoO}_{4}\right)$ and sulfates $\left(\mathrm{MgSO}_{4}\right)$. Lattice $\mathrm{O}^{2-}$ (nearly 57 at.\% in content) was positioned at $530.44 \mathrm{eV}$, while 7 at $\%$ interstitial $\mathrm{O}^{2-}$ was positioned at $531.1 \mathrm{eV}$. The level of interstitial oxygen was significantly lower in intensity in comparison to that identified for the assynthesized case due to oxygen loss during sensor operation. Due to the fact that the sensor was cooled down in a $\mathrm{N}_{2}$ atmosphere, the oxygen used or expulsed during high temperature testing was not replenished. Another portion of the oxygen 1s peak was positioned at $532.75 \mathrm{eV}$, which is attributed to the S-O bonds (nearly 36 at.\%); this position matches well with the value reported by Sugiyama et al. $[86]$.

The XPS analysis shows that nearly a third of the oxygen is correlated to a sulfate composition on the surface of the sensing material. This result aligns well with the idea that the sensor surface is saturated with sulfur species, which limits further reaction with $\mathrm{SO}_{2}$ within the gas stream. As seen in our previous work, the nano- $\mathrm{SrMoO}_{4}$ remained as a highly sensitive material due to the adsorbed sulfur at high temperature [16]. After the inclusion of the $\mathrm{MgO}$ as a second-phase (and dissolved into solution), the formation of $\mathrm{MgSO}_{4}$ appeared to limit further $\mathrm{SO}_{2}$ reaction (and possible diffusion) [87]. Even with this formation, the presence of this sulfate permits continuous functioning of the adsorption and redox reaction with $\mathrm{H}_{2}$. In this case, initially $\mathrm{H}_{2}$ may reduce the $\mathrm{MgSO}_{4}$ to $\mathrm{Mg}$ and $\mathrm{H}_{2} \mathrm{SO}_{4}$, and subsequently in the sulfur deprived and oxygen rich environment, $\mathrm{Mg}$ may then re-oxidize to MgO. The XPS spectra for the sulfur (S) 2p was also characterized for the same sample and this data is presented in Fig. 12-b. Sulfur was detected in the form of $\mathrm{MgSO}_{4}$ in addition to $\mathrm{MgS}_{1-\mathrm{x}}$ and trapped $\mathrm{SO}_{2} / \mathrm{S}$. The deconvolution of the corresponding S 2p peak provided information regarding the relative amount of each phase. The deconvolution of the sulfur spectra indicated that the sulfur resided in forms of $\mathrm{MgS}_{1-\mathrm{x}}, \mathrm{SO}_{2} / \mathrm{S}$ and 
$\mathrm{MgSO}_{4}$, where the sulfur concentration was $10.2,12.5$ and 77.3 at.\%, respectively. The binding energies measured for sulfur in $\mathrm{MgSO}_{4}, \mathrm{SO}_{2} / \mathrm{S}$ and $\mathrm{MgS}_{1-\mathrm{x}}$ were 169.0, 165.4 and $163.1 \mathrm{eV}$, respectively. The values are an excellent match with the literature values $[86,88,89,90]$. In stoichiometric $\mathrm{MgS}$, the $2 \mathrm{p}_{3 / 2}$ electrons belong to sulfur having the binding energy values of $162.0 \mathrm{eV}$ [91]; however, in our measurements, the value was $1.1 \mathrm{eV}$ higher which corresponds to a sulfur deficient compound of $\mathrm{MgS}$. It was not possible to distinguish elemental eight-coordinated sulfur from the trapped $\mathrm{SO}_{2}$, since both possess close binding energy values.

\section{Reduction Characterization of $\mathrm{SrMoO}_{4} / \mathrm{MgO}$ with Temperature Programmed Reduction (TPR)}

The temperature programmed reduction (TPR) technique was utilized to further investigate the reduction process of the nano- $\mathrm{SrMoO}_{4}$ and $\mathrm{SrMoO}_{4} / \mathrm{MgO}$. By this technique, it was possible to further justify the high sensitivity of $\mathrm{SrMoO}_{4} / \mathrm{MgO}$ towards $\mathrm{H}_{2}$ in comparison to the nano-SrMoO 4 . Kubo et al. concluded that the reduction of $\mathrm{SrMoO}_{4}$ to $\mathrm{SrMoO}_{3}$ starts at $650^{\circ} \mathrm{C}$ under hydrogen flow without any oxygen background [92]. The TPR isotherms for nano- $\mathrm{SrMoO}_{4}$ and $\mathrm{SrMoO}_{4} / \mathrm{MgO}$ are presented in Fig. 13. The isotherms represent consumption of $\mathrm{H}_{2}$ with increasing temperature starting from room temperature until $910^{\circ} \mathrm{C}$. The TPR measurement was completed by increasing the temperature to $910^{\circ} \mathrm{C}$ at a rate of $5{ }^{\circ} \mathrm{C} / \mathrm{min}$ in $10 \% \mathrm{H}_{2} / \mathrm{Ar}$ atmosphere. The nano- $\mathrm{SrMoO}_{4}$ showed two $\mathrm{H}_{2}$ consumption peaks that were located at $576^{\circ} \mathrm{C}$ and $825^{\circ} \mathrm{C}$. The first reduction was nearly $25^{\circ} \mathrm{C}$ lower than that reported by Kubo et al., and the second reduction was observed nearly $90^{\circ} \mathrm{C}$ higher in temperature [92]. The $\mathrm{SrMoO}_{4} / \mathrm{MgO}$ exhibited a similar reduction behavior with almost identical peak positions, but the magnitude of these peaks were an order of magnitude higher in peak intensity. Between $130^{\circ} \mathrm{C}$ and $400^{\circ} \mathrm{C}$, it is assumed that the $\mathrm{SrMoO}_{4} / \mathrm{MgO}$ released $\mathrm{H}_{2}$ due to the decomposition of $\mathrm{Mg}(\mathrm{OH})_{2}$, since the consumption values were negative. $\mathrm{Mg}(\mathrm{OH})_{2}$ and $\mathrm{MgH}_{2}$ decompose at $300^{\circ} \mathrm{C}$ and $285^{\circ} \mathrm{C}$, respectively [93]. The release of the $\mathrm{H}_{2}$ was immediately followed by a rapid and intensive consumption of $\mathrm{H}_{2}$ starting from $400^{\circ} \mathrm{C}$. The first reduction maximum for $\mathrm{SrMoO}_{4} / \mathrm{MgO}$ was observed at $\sim 575^{\circ} \mathrm{C}$, and the signal output was proportional to 
the consumption of $\mathrm{H}_{2}$. The relative intensity change was $\sim 22$ times greater than that measured for nano$\mathrm{SrMoO}_{4}$. The second reduction maximum was observed around $830^{\circ} \mathrm{C}$, and the consumption of $\mathrm{H}_{2}$ was increased with the increase of temperature until the test was completed at $910^{\circ} \mathrm{C}$. Based on the TPR results, it may be assumed that this significant increase was due to the high adsorption and dissociative nature of $\mathrm{H}_{2}$ on $\mathrm{MgO}$. This subsequently increased the reduction kinetics of nano- $\mathrm{SrMoO}_{4}$ based on the higher $\mathrm{H}^{+}$concentration. Although it is still debatable about the exact mechanism of $\mathrm{H}_{2}$ adsorption and dissociation over $\mathrm{MgO}$ [22], it is well-known that $\mathrm{MgO}$ supports hydrogen dissociation on cation-anion couples, especially with the lowest coordination $[94,95,23,22]$. Some literature attributes this to divacancy defect sites $[96,20,21][97]$.

\section{6. $\mathrm{H}_{2}$ Sensing Comparison of $\mathrm{SrMoO}_{4} / \mathrm{MgO}$ to $\mathrm{SrMoO}_{4}-\mathrm{MgO}$ Composite}

In order to better understand the relative influence of the $\mathrm{MgO}$ substitution into the nano- $\mathrm{SrMoO}_{4}$, $\mathrm{MgO}$ was precipitated onto the surface of nano- $\mathrm{SrMoO}_{4}$ to purposely form just the composite composition. In this case, $\mathrm{MgO}$ would only remain as a secondary phase on the surface of the nano$\mathrm{SrMoO}_{4}$, and would not be dissolved into the $\mathrm{SrMoO}_{4}$ structure (thus, not modifying the electronic structure). As discussed throughout the paper, it was shown that the $\mathrm{SrMoO}_{4} / \mathrm{MgO}$ contains both $\mathrm{MgO}$ on the surface of the $\mathrm{SrMoO}_{4} / \mathrm{MgO}$ sensor material and dissolved into the nano- $\mathrm{SrMoO}_{4}$ scheelite structure. We have proposed that the $\mathrm{MgO}$ allows for improved $\mathrm{H}_{2}$ adsorption and dissociation, and the $\mathrm{MgO}$ protects against $\mathrm{SO}_{2}$ interference and poisoning. The dissolved $\mathrm{Mg}$ is altering the work function, bandgap and activation energy which all increasingly contributed to the sensor response by reducing interconnect and grain boundary Schottky barriers.

In order to have a clearer understanding on the benefit of the electronic modification, $\mathrm{MgO}$ was added to the nano- $\mathrm{SrMoO}_{4}$ with the exact amount that was measured by AAS. The amount was incorporated into the nano- $\mathrm{SrMoO}_{4}$ by mechanical mixing. $\mathrm{MgO}$ micro-fibers and nano- $\mathrm{SrMoO}_{4}$ aqueous mixture were heated at $180^{\circ} \mathrm{C}$ for $2 \mathrm{~h}$ on a hotplate without the hydrothermal processing until the mixture was dried. These powders were similarly printed onto the electrode alumina substrates and fired in the same manner 
as all of the other sensors fabricated in this work. The composite sensor material was tested for $\mathrm{H}_{2}$ and $\mathrm{SO}_{2}$ sensing using the previously described testing procedures. The relative resistance change curve for $\mathrm{H}_{2}$ at $1000^{\circ} \mathrm{C}$ is presented in Fig. 14-a. The testing results for $\mathrm{SrMoO}_{4} / \mathrm{MgO}$ and nano-SrMoO${ }_{4}$ are also presented in Fig.14-b and c for comparison purposes. The $R_{\max }$ value for $\mathrm{SrMoO}_{4}-\mathrm{MgO}$ composite against $4000 \mathrm{ppm}$ of $\mathrm{H}_{2}$ was -32.2 ; this value was considerably higher in comparison to the nano- $\mathrm{SrMoO}_{4}$ alone, which was -7.5; however, it was significantly lower than the $R_{\max }$ of $\mathrm{SrMoO}_{4} / \mathrm{MgO}$ (-87.2). This result confirms the catalytic influence of the $\mathrm{MgO}$ secondary phase on the nano- $\mathrm{SrMoO}_{4}$ sensing material. For a final comparison of the mechanically-formed $\mathrm{SrMoO}_{4}-\mathrm{MgO}$ composite to the $\mathrm{SrMoO}_{4} / \mathrm{MgO}$ material, the $\mathrm{SrMoO}_{4}-\mathrm{MgO}$ composite was also tested for $\mathrm{SO}_{2}$ cross-selectivity as the previous sensors. The $\mathrm{SrMoO}_{4}-\mathrm{MgO}$ composite exhibited similar insensitivity (data not included). The very first exposure on the testing sequence was detected with the $R_{\max }$ value of -36 ; however, the remaining exposures were detected with very low $R_{\max }$ values due to poisoning of the surface. The similar compound formation (data not included) between $\mathrm{MgO}$ and $\mathrm{SO}_{2}$ was observed after the testing of this $\mathrm{SrMoO}_{4}-\mathrm{MgO}$ composite.

These experiments furthered the understanding of the influence of the $\mathrm{MgO}$ second-phase to the $\mathrm{SrMoO}_{4}$ sensing capabilities. A general summary of the contribution of the $\mathrm{MgO}$ to the sensor response is presented schematically in Fig.14. The figure shows the general sensor response, microstructure and attribute list for the three compositions tested in this work between Pt IDE electrodes. Again, the compositions tested in this work were the pure nano-SrMoO 4 , the hydrothermally-synthesized $\mathrm{SrMoO}_{4} / \mathrm{MgO}$ composite, and the mixed $\mathrm{SrMoO}_{4}-\mathrm{MgO}$ composite (in order from bottom to top in the figure). First, comparing the microstructural difference, the porosity in the pure nano-SrMoO 4 (bottom of figure) was low after sensor testing, indicating that significant densification occurred during testing. In the case of the $\mathrm{SrMoO}_{4}-\mathrm{MgO}$ composite (top of figure), the porosity was more prevalent throughout the structure, which indicates that the $\mathrm{MgO}$ second-phase limited the densification mechanism. Also, this $\mathrm{MgO}$ pinning controlled the grain growth process, where the grain size was limited to a finer size compared to its nano- $\mathrm{SrMoO}_{4}$ counterpart. 
The $\mathrm{SrMoO}_{4} / \mathrm{MgO}$ composite (middle of figure) showed the very fiborous composite structure with pores $>30 \mu \mathrm{m}$ in size. The final $\mathrm{SrMoO}_{4} / \mathrm{MgO}$ micro-fibers were composed of grains in the size range of $\sim 1-10 \mu \mathrm{m}$ after testing, which coarsened from the original $\sim 50 \mathrm{~nm}$ size range, but stabilized during prolonged testing. The more open microstructure was attributed to the packing of the fiberous material, and the presence of residual $\mathrm{MgO}$ secondary-phase (limiting the grain growth of the $\mathrm{SrMoO}_{4}$ sub-grains in the fiber). The increased porosity level of both the $\mathrm{SrMoO}_{4}-\mathrm{MgO}$ and $\mathrm{SrMoO}_{4} / \mathrm{MgO}$ composites would permit better mass diffusion of the sensing gas, and thus, a higher exposure rate to the $\mathrm{H}_{2}$ gas. Comparing the influence of the second-phase $\mathrm{MgO}$ on the electrochemical response, the additional $\mathrm{MgO}$ was shown to permit a high level of $\mathrm{H}_{2}$ adsorption and spill-over to the sensing material. In the case of the pure nano- $\mathrm{SrMoO}_{4}$ (bottom of figure), without the addition of $\mathrm{MgO}$, the response was lower than either of the compositions with $\mathrm{MgO}$. The highest sensor response was obtained for the hydrothermally-derived $\mathrm{SrMoO}_{4} / \mathrm{MgO}$ (middle of figure), stemming from the incorporation of the second-phase $\mathrm{MgO}$. The further performance improvement over the mixed $\mathrm{SrMoO}_{4}-\mathrm{MgO}$ composite (top of figure) was attributed to both the enhanced $\mathrm{H}_{2}$ adsorption (potentially due to a better $\mathrm{MgO}$ dispersion or content) and the electronic modification of the intrinsic $\mathrm{SrMoO}_{4}$ composition. The $\mathrm{SrMoO}_{4} / \mathrm{MgO}$ compostion was shown to have a lower work function $(7.7 \mathrm{eV})$ over the pure nano- $\mathrm{SrMoO}_{4}(9.3 \mathrm{eV})$. This alteratnion would increase $\mathrm{H}_{2}$ sensitivity due to a relatively lower barrier height between the Pt electrode and sensing material interface (). In addition, the activation energy calculations showed that the Schottky barrier height () among the grains was also lower for the $\mathrm{SrMoO}_{4} / \mathrm{MgO}$ material, which would lead to higher electron conductivity through the sensing material. Moreover, the bang gap value for $\mathrm{SrMoO}_{4} / \mathrm{MgO}$ was lower than that of nano- $\mathrm{SrMoO}_{4}$. Overall, these attributes would all lead to more accessible electrons for both conduction and redox reactions. The influence of the highly porous microstructure of the $\mathrm{SrMoO}_{4} / \mathrm{MgO}$ also conributed to the high response.

\section{Conclusion}


The work presented the hydrothermal synthesis and characterization of $\mathrm{MgO}$-enhanced $\mathrm{SrMoO}_{4}$ composition which was used as a sensing material in a resistive-type, solid-state gas sensor. The material was synthesized by providing $\mathrm{MgO}$ micro-fibers as seed particles into a $\mathrm{SrMoO}_{4}$ hydrothermal synthesis reaction. The $\mathrm{MgO}$ micro-fibers acted as a nucleation site for $\mathrm{SrMoO}_{4}$ formation, but did not template the orientation of the composition. Interestingly, as the $\mathrm{SrMoO}_{4}$ grew on the $\mathrm{MgO}$ particles, the $\mathrm{MgO}$ concurrently dissolved back into the aqueous medium (leaving a portion dissolved within the $\mathrm{SrMoO}_{4}$ crystal structure). The $\mathrm{MgO}$ micro-fibers acted like a transient template for the formation of the $\mathrm{SrMoO}_{4}$ phase. The final obtained powder retained the general $\mathrm{MgO}$ acicular morphology and particle size, but a core $\mathrm{MgO}$ phase was not found within the resultant $\mathrm{SrMoO}_{4}$ particles. Although the $\mathrm{MgO}$ was not discovered as a second-phase within the $\mathrm{SrMoO}_{4}$ particles, it was found to re-deposit onto the surface of the final particles. In the end, the final acicular structure of the $\mathrm{SrMoO}_{4}$ powder was found to be stable for high-temperature sensor testing, where the microstructure remained consistent without significant sintering or grain growth.

The inclusion of both $\mathrm{Mg}$ dissolved into the $\mathrm{SrMoO}_{4}$ lattice and $\mathrm{MgO}$ remaining on the surface of the particles significantly altered the sensing capabilities of the composition, which was different than that found in our previous work. In our previous work, the $\mathrm{SrMoO}_{4}$ composition showed poor $\mathrm{H}_{2}$ sensing capabilities, but showed relatively high response to sulfur species (such as $\mathrm{SO}_{2}$ and $\mathrm{H}_{2} \mathrm{~S}$ ). In the current work, the $\mathrm{MgO}$-modified $\mathrm{SrMoO}_{4}$ showed very low sulfur sensitivity due to the formation of surface $\mathrm{MgS} / \mathrm{MgSO}_{4}$, which we presume poisoned the surface from further sulfur oxidation. In the case of $\mathrm{H}_{2}$ sensing, the MgO-modified $\mathrm{SrMoO}_{4}$ showed relatively high sensitivity toward $\mathrm{H}_{2}$, which was again different from that found in our previous work for the pure $\mathrm{SrMoO}_{4}$ composition. It was found in this work that the $\mathrm{Mg}$-modification altered the band gap and work function from pure $\mathrm{SrMoO}_{4}$ significantly, which could contribute to some of this difference. One result of these electronic changes affected the height of the Schottky barriers between the Pt metal interconnect and semi-conducting oxide interface within the sensor; the Schottky barriers among the bulk grains within the sensing material were also 
affected. Finally, the additional $\mathrm{MgO}$ second-phase on the $\mathrm{SrMoO}_{4}$ surface was assumed to enhance the hydrogen adsorption and dissociation at the elevated temperatures, where the pure $\mathrm{SrMoO}_{4}$ showed low hydrogen reaction at the same temperatures. All of the above attributes for the $\mathrm{MgO}$-modified $\mathrm{SrMoO}_{4}$ sensing material lead to adequate sensing of $\mathrm{H}_{2}$ at relatively high temperatures. Future work will focus on further testing of $\mathrm{H}_{2}$ at even lower concentrations than that demonstrated in this work, in addition to lower $\mathrm{pO}_{2}$ levels. In addition, further work must be completed to better understand the compositional range of dissolved and surface $\mathrm{MgO}$ on the electrical properties, $\mathrm{H}_{2}$ adsorption/dissociation, and poison surface reactions.

\section{Acknowledgement}

This work was supported by the Department of Energy under Award Number DE-FE0003872. We acknowledge the use of the WVU Shared Research Facilities. The authors also would like to thank Dr. Kolin Brown, Dr. Wei Ding, and Mr. Chuck Coleman for their assistance.

\section{References}

[1] L. Schlapbach and A. Züttel, Nature, vol. 414, p. 353, 2001.

[2] L. Chi, Kentucky: University of Kentucky Doctoral Dissertations, 2009.

[3] C. Wildfire, E. Ciftyurek, K. Sabolsky and E. M. Sabolsky, J.Mater. Sci., vol. 49, pp. 4735-4750, 2014.

[4] G. Korotcenkov, S. Do Han and J. R. Stetter, Chem. Rev., vol. 109, pp. 1402-1433, 2009.

[5] J. Larminie and A. Dicks, Chichester,West Sussex, UK: John Wiley \& Sons, 2nd ed., 2003.

[6] G. Lu, N. Miura and N. Yamazoe, Sens. Actuators B Chem., vol. 35, p. 130, 1996.

[7] E. Ciftyurek, K. Sabolsky and E. M. Sabolsky, Sens. Actuators B Chem., vol. 181, p. 702-714, 2013.

[8] E. Ciftyurek, C. D. McMillen, K. Sabolsky and E. M. Sabolsky, Sens. Actuators B Chem., vol. 207, pp. 206-215, 2015.

[9] C. Wildfire, E. Ciftyurek, K. Sabolsky and E. M. Sabolsky, J. Electrochem. Soc., vol. 161, no. 2, pp. B3094-B3102, 2014. 
[10] J. Song, W. Lu, S. F. Jeffery and G. R. Barndes, Appl. Phys. Lett., vol. 87, p. 133501, 2005.

[11] M. Fleischer and H. Meixner, Sens. Actuators B Chem., vol. 52, pp. 179-187, 1998.

[12] C. Lu and Z. Chen, Sens. Actuators B Chem., vol. 140, pp. 109-115, 2009.

[13] A. L. Spetz, A. Baranzahi, P. Tobias, I. Lundstrom, Phys. Stat. Sol. (a), vol.162, pp.493-511, 1997.

[14] F. Qu, H. Jiang and M. Yang, Nanoscale, vol. 8, p. 16349, 2016.

[15] F. Qu, Y. Yuan, R. Guarecuco and M. Yang, Small, vol. 23, p. 3128-3133, 2016.

[16] E. Ciftyurek, K. Sabolsky and E. M. Sabolsky, Sens. Actuators B Chem., vol. 237, pp. 262-274, 2016.

[17] S. Freni, S. Cavallaro, N. Mondello, L. Spadaro, F. Frusteri, Catal. Commun., vol.4, p.259-268, 2003.

[18] J. I. Di Cosimo, V. K. Diez, C. Ferretti and C. R. Apesteguia, Catalysis, vol.26, pp.1-28, 2014.

[19] J. J. Ramos, V. K. Diez, C. A. Ferretti, P. A. Torresi, C. R. Apesteguia and J. I. Di Cosimo, Catal. Today, vol. 172, pp. 41-47, 2011.

[20] T. Ito, T. Murakami and T. Tokuda, J. Chem. Faraday Trans., vol. 79, no. 1, pp. 913-924, 1983.

[21] E. Knozinger, K. H. Jacop and P. Hofmann, J. Chem. Soc. Faraday Trans., vol. 1989, no. 7, pp. 1101-1107, 1993.

[22] K. Sawabe, N. Koga and K. Morokuma, J. Chern. Phys., vol. 97, no. 9, pp. 6871-6879, 1992.

[23] S. Coluccia, F. Boccuzzi, G. Ghiotti and C. Morterra, J. Chem. Soc., Faraday Trans. 1, vol. 78, pp. 2111-2119, 1982.

[24] M. Boudart, A. Delbouille, E. G. Derovane, V. Indovina and A. B. Wlaters, J. Am. Cehm. Soc., vol. 94, p. 6622, 1972.

[25] A. D’Ercole and C. Pisani, J. of Chem. Phys,, vol. 111, no. 21, pp. 9743-9353, 1999.

[26] E. Garrone and F. S. Stone, J. Chem. Soc. Faraday Trans., vol. 83, p. 1237, 1987.

[27] H.-Y. T. Chen, L. Giordano and G. Pacchioni, J. Phys. Chem. C, vol. 117, no. 10623-10629, 2013.

[28] G. Wu, J. Zhang, Y. Wu, Q. Li, K. Chou and X. Bao, J. Alloys Compd., vol. 480, pp. 788-793, 2009. 
[29] A. Borgschulte, M. Bielmann, A. Zuttel, G. Barkhordarian, M. Dornheim and R. Bormann, Appl. Surf. Sci., vol. 254, pp. 2377-2384, 2008.

[30] X. Sun, J. Y. Hwang and S. Shi, J. Phys. Chem. C, vol. 114, pp. 7178-7184, 2010.

[31] A. Janotti and C. G. Van De Walle, Nature Materials, vol. 6, pp. 44-47, 2007.

[32] J. Gebhardt, F. Vines, P. Bleiziffer, W. Hieringer and A. Gorling, Phys.Chem.Chem.Phys, vol. 16, pp. 5382--5392, 2014.

[33] A. A. Al-Ghamdi, F. Al-Hazmi, F. Alnowaiser, R. M. Al-Tuwirqi, A. A. Al-Ghamdi and A. O. Alhartomy, J. of J Electro., p. 198, 2012.

[34] A. M. Azad, S. G. Mhaisalkar, L. D. Birkefeld, S. A. Akbar and K. S. Goto, J. Electrochem. Soc, vol. 139, no. 10, pp. 2913-2920, 1992.

[35] J. F. Moulder, W. F. Stickle, P. E. Sobol and K. D. Bomben, Chigasaki, Japan: ULVAC-PHI. Inc., 1992-1995.

[36] W. Chen, C. S. Chen and L. Winnubst, Solid state Ionics, vol. 196, pp. 30-33, 2011.

[37] Q. Zeng, Y. B. Zuo, C. G. Fan and C. S. Chen, J. Membr. Sci., vol. 335, pp. 140-144, 2009.

[38] J. C. Dupin, . G. Danielle, V. Philippe and . L. Alain, Phys. Chem. Chem. Phys, vol. 2, pp. 1319$1324,2000$.

[39] J.-C. Wang, D.-Y. Jian, Y.-R. Ye, L.-C. Chang and C.-S. Lai, J. Phys. D: Appl. Phys, vol. 46, 2013.

[40] X. Zhang, J. Qin, Y. Xue, Y. Pengfei, B. Zhang, B. Wang, L. Wang and R. Liu, Sciebtific Reports, vol. 4, p. 4596, 3014.

[41] S. K. Pandey, S. K. Pandey, U. P. Deshpande, V. Awasthi, K. Ashish, G. Mukul and M. Shaibal, Semicond. Sci. Technol., vol. 25, p. 085014, 2013.

[42] H. W. Huang, Z. G. Ye, M. Dong, W. L. Zhu and X. Q. Feng, Jpn. J. Appl. Phys., vol. 41, p. L 713L 715, 2002.

[43] M. E. Labib, Colloids Surf., vol. 29, no. 3, pp. 293-304, 1988.

[44] A. O. Menezes, P. S. Silvia, E. P. Hernandez, L. E. Borges and M. A. Fraga, Langmuir, p. 3382, 2010.

[45] Z. Yang, R. Wu, Q. Zhang and D. W. Goodman, Phys. Rev. B., vol. 65, no. 15, p. 155407, 2002. 
[46] W. J. Price, Cambridge: Heyden\&Son LTD, 1972.

[47] M. Karlsteen, A. Baranzahi, L. A. Spetz, M. Willander and I. Lundstrom, J. Electron. Mater., vol. 24, no. $7,1995$.

[48] U. Hoefer, J. Frank and M. Fleischer, Sens. Actuators B Chem., vol. 78, pp. 6-11, 2001.

[49] C. Barshick, D. Duckworth and D. Smith, New York City: Marcek Dekker, Inc., 2000.

[50] D. L. Wood and J. Tauc, Phys. Rev. B, vol. 5, pp. 3144-3146, 1972.

[51] R. L. Perales, J. R. Fuertes, D. Errandonea, M. Garcia and A. Sugura, Europhysic Lett., vol. 83, pp. 37002-37008, 2008.

[52] J. C. Sczancoski, L. S. Cavalcante, M. R. Joya, J. A. Varela, P. S. Pizani and E. Longo, Chem. Engin. J., vol. 140, pp. 632-637, 2008.

[53] S. Wannapop, T. Thongtem and S. Thongtem, National Reserach Univeristy of Thailand, 2012.

[54] S. Vidya, A. John, S. Solomon and J. K. Thomas, Adv. Mat. Res., vol. 1, no. 3, pp. 191-204, 2012.

[55] T. Thongtem, S. Kungwankunakorn, B. Kuntalau, A. Phuruangrat and S. Thongtem, J. Alloys Compd., vol. 506, pp. 475-481, 2010.

[56] O. E. Taurian, M. Springborg and N. E. Christensen, Solid State Commun., vol. 55, no. 4, pp. 351$355,1984$.

[57] B. Tatar, F. P. Gokdemir, E. Pehlivan and M. Urgen, Appl. Surf. Sci., vol. 285, no. Part B, pp. 409416, 2013.

[58] S. Song, C. Wang, F. Hong, Z. Hw, Q. Cai and J. Chen, App. Surf. Sci., vol. 257, no. 8, pp. 3427$3432,2010$.

[59] K. H. Ng, L. J. Minggu and M. B. Kassim, Int. J. Hydrogen. Ener., vol. 38, no. 22, pp. 9585-9591, 2013.

[60] K. D. Schierbaum, U. Weimer, W. Gopel and R. Kowalkowski, Sens. Actuators B Chem., vol. 3, no. 3, pp. 205-214, 1991.

[61] B. K. Maji, H. Jena, R. Asuvathraman and K. G. Kutty, J. Alloys Compd., vol. 640, pp. 475-479, 2015.

[62] A. S. Foster, A. L. Shluger and R. M. Nieminen, Phys. Rev. Lett., vol. 89, p. 225901, 2002. 
[63] G. Blyholder and M. Lawless, Langmuir, vol. 7, pp. 140-141, 1991.

[64] U. Heiz, A. Sanhez, S. Abbet and W. D. Schneider, J. Am. Chem. Soc., vol. 121, p. 3214, 1999.

[65] R. S. C. Smart, T. L. Slager, L. H. Little and R. G. Greenler, J. Phys. Chem., vol. 77, no. 8, p. 1019, 1973.

[66] H. Hattori, H. Imai and H. Itoh, Chem. Lett., pp. 1311-1314, 1981.

[67] A. J. Goodsel, M. D. Low and N. Takezawa, Environ. Sci. Technol., vol. 6, no. 3, pp. 268-273, 1972.

[68] L. Li and D. L. King, Ind. Eng. Chem. Res., vol. 44, pp. 168-177, 2005.

[69] H. Y. Sohn and D. H. Han, AIChE J., vol. 48, p. 2985, 2002.

[70] W. Lapple and R. Matty.USA Patent US3758668A, 11 Sep. 1973.

[71] Y.-X. Li, H. Li and K. J. Klabunde, Environ. Sci. Technol., vol. 28, pp. 1248-1253, 1994.

[72] Y.-X. Li, J. R. Schlup and K. J. Klabunde, Langmuir, pp. 1394-1399, 1991.

[73] A. Khaleel, P. N. Kapoor and K. J. Klabunde, Nanostruct. Mater., vol. 11, no. 4, pp. 459-468, 1999.

[74] O. B. Koper, I. Lagadic, A. Volodin and K. J. Klabunde, Chem. Mater., vol. 9, pp. 2468-2480, 1997.

[75] G. W. Wagner, P. W. Bartram, O. Koper and K. J. Klabunde, J. Phys. Chem. B, vol. 103, pp. 3225$3228,1999$.

[76] G. Pacchioni, M. J. Ricart and F. Illas, J. Am. Chem. Soc., vol. 116, pp. 10152-10158, 1994.

[77] G. Pacchioni, A. Clotet and J. M. Ricart, Surf. Sci., vol. 315, no. 3, pp. 337-350, 1994.

[78] V. V. Pechkovsky, J. Appl. Chem. USSR, vol. 30, p. 873, 1957.

[79] M. Schnitzer, J. R. Wright and I. Hoffman, Anal. Chim. Acta, vol. 26, pp. 371-377, 1962.

[80] K. H. Stern and E. L. Weise, United State Department of Commerce, Washington, D.C., 1966.

[81] E. T. Turkdogan and B. B. Rice, Metall. Trans. A, vol. 5, p. 1537, 1974.

[82] S. J. Lee, S. Y. Jung, S. C. Lee, H. K. Jun, C. K. Ryu and J. C. Kim, Ind. Eng. Chem. Res., vol. 48, pp. 2691-2696, 2009.

[83] S. C. Lee, B. W. Hwang, S. J. Lee, H. Y. Choi, S. Y. Kim, S. Y. Jung, D. Ragupathy and D. D. Lee, Sens. Actuators B Chem., vol. 160, no. 1, pp. 1328-1334, 2011. 
[84] J. Plewa and J. Steindor, J. Therm. Anal., vol. 32, no. 6, pp. 1809-1820, 1987.

[85] K. Ding, S. Wang, S. Li and C. Yue, Geochem. J., vol. 45, pp. 97-108, 2011.

[86] S. Sugiyama, T. Miyamoto, H. Hayashi and J. B. Moffat, Bull. Chem. Soc. Jpn., vol. 69, pp. 235240, 1996.

[87] N. Z. Fotoyi and R. H. Eric, Southern African Pyrometallurgy, 2011.

[88] H. S. Kim, T. S. Arthur, G. D. Allred, Zajicekj, J. G. newman, A. E. Rodnyansky, A. G. Oliver, W. C. Boggess and J. Muldon, Nat. Commun., vol. 2, no. 427, 2011.

[89] Y. M. Shul'ga, V. I. Rubtsov, V. N. Vasilets, A. S. Lobach, N. G. Spitsyna and E. B. Yagubskii, Synthetic Metals, vol. 70, no. 1381, 1995.

[90] T. Yokoyama, A. Imanishi, S. Tereda, H. Nambe, Y. Kitajima and T. Ohta, Surf. Sci., vol. 334, no. $88,1995$.

[91] H. F. Franzen, M. X. Umana, J. R. McCreary and R. J. Thorn, J. Solid State Chem., vol. 18, no. 363, 1976.

[92] J. Kubo and W. Ueda, Mater. Res. Bull., vol. 44, no. 4, pp. 906-912, 2009.

[93] Y. Inoue and I. Yasumori, Bull. Chem. Soc. Jpn., vol. 54, pp. 1505-1510, 1981.

[94] H. Kobayashi, D. R. Salahub and T. Ito, J. Phys. Chem., vol. 98, pp. 5487-5492, 1994.

[95] T. Shido, K. Asakura and Y. Iwasawa, J. Chem. SOC., Faraday Trans. I, vol. 85, no. 2, pp. 441-453, 1989.

[96] S. Coluccia, L. Marchese, S. Lavagnino and M. Anpo, Spectrochimica Acta, vol. 43A, no. 12, pp. 1573-1576, 1987.

[97] S. Coluccia and A. J. Tench, Stud. Surf. Sci. Catal., vol. 7, no. Part B, pp. 1154-1169, 1981.

\section{List of Figures:}

Figure 1: SEM micrographs of as-synthesized (a) $\mathrm{MgO}$ micro-fibers (b) $\mathrm{SrMoO}_{4} / \mathrm{MgO}$ (c) $\mathrm{SrMoO}_{4} / \mathrm{MgO}$ and (d)nano- $\mathrm{SrMoO}_{4}$ after $5 \mathrm{~h}$ at $1000^{\circ} \mathrm{C}$.

Figure 2: XPS core spectrum of $\mathrm{Sr}, \mathrm{O}$ and $\mathrm{Mo}$ in the as-synthesized (a) nano- $\mathrm{SrMoO}_{4}$ and (b) $\mathrm{SrMoO}_{4} / \mathrm{MgO}$. 
Figure 3: The at $\%$ concentration of $\mathrm{Mg}, \mathrm{Sr}, \mathrm{O}$ and $\mathrm{Mo}$ at different depths through the $\mathrm{SrMoO}_{4} / \mathrm{MgO}$.

Figure 4: SEM image of $\mathrm{pH} 8$ treated $\mathrm{MgO}$. The inset provides a higher magnification of the $\mathrm{MgO}$ micro-fibers.

Figure 5: The chemical state of $\mathrm{Mg}$ at different depths through the $\mathrm{SrMoO}_{4} / \mathrm{MgO}$.

Figure 6: XRD spectrum of $\mathrm{SrMoO}_{4} / \mathrm{MgO}$ and nano- $\mathrm{SrMoO}_{4}$.

Figure 7: Schematic of sensor architecture, sensing material, Schottky barriers.

Figure 8: $\mathrm{A}$ Uv-Vis bandgap measurements for $\mathrm{SrMoO}_{4} / \mathrm{MgO}$ micro-fibers and nano-SrMoO .

Figure 9: $\mathrm{Ln}(\mathrm{R})$ vs. $\left(\mathrm{k}_{\mathrm{B}} \mathrm{T}\right)^{-1}$ plot for the nano-SrMoO 4 and $\mathrm{SrMoO}_{4} / \mathrm{MgO}$.

Figure 10: The relative resistance change curves $(R)$ for $\mathrm{SrMoO}_{4} / \mathrm{MgO}$ tested in $\mathrm{H}_{2}$ at (a) 600, (b) 800 and (c) $1000^{\circ} \mathrm{C}$.

Figure 11: Maximum relative resistance change versus temperature for $\mathrm{CO}$ and $\mathrm{SO}_{2}$ crossselectivity testing for the $\mathrm{SrMoO}_{4} / \mathrm{MgO}$ composite.

Figure 12 : XPS analysis of the $\mathrm{SrMoO}_{4} / \mathrm{MgO}$ sensor material after testing in $\mathrm{SO}_{2}$. The $\mathrm{O}$ 1s (a) and S $2 \mathrm{p}$ (b) positions are presented.

Figure 13: TPR measurements of nano- $\mathrm{SrMoO}_{4}$ and $\mathrm{SrMoO}_{4} / \mathrm{MgO}$.

Figure 14: Relative resistance change (R) for (a) $\mathrm{SrMoO}_{4}-\mathrm{MgO}$ composite (b) $\mathrm{SrMoO}_{4} / \mathrm{MgO}_{\text {(c) }}$ Nano- $\mathrm{SrMoO}_{4}$ tested at $1000^{\circ} \mathrm{C}$ for $\mathrm{H}_{2}$. 


\section{Growth of nano-SrMoO, over MigO}

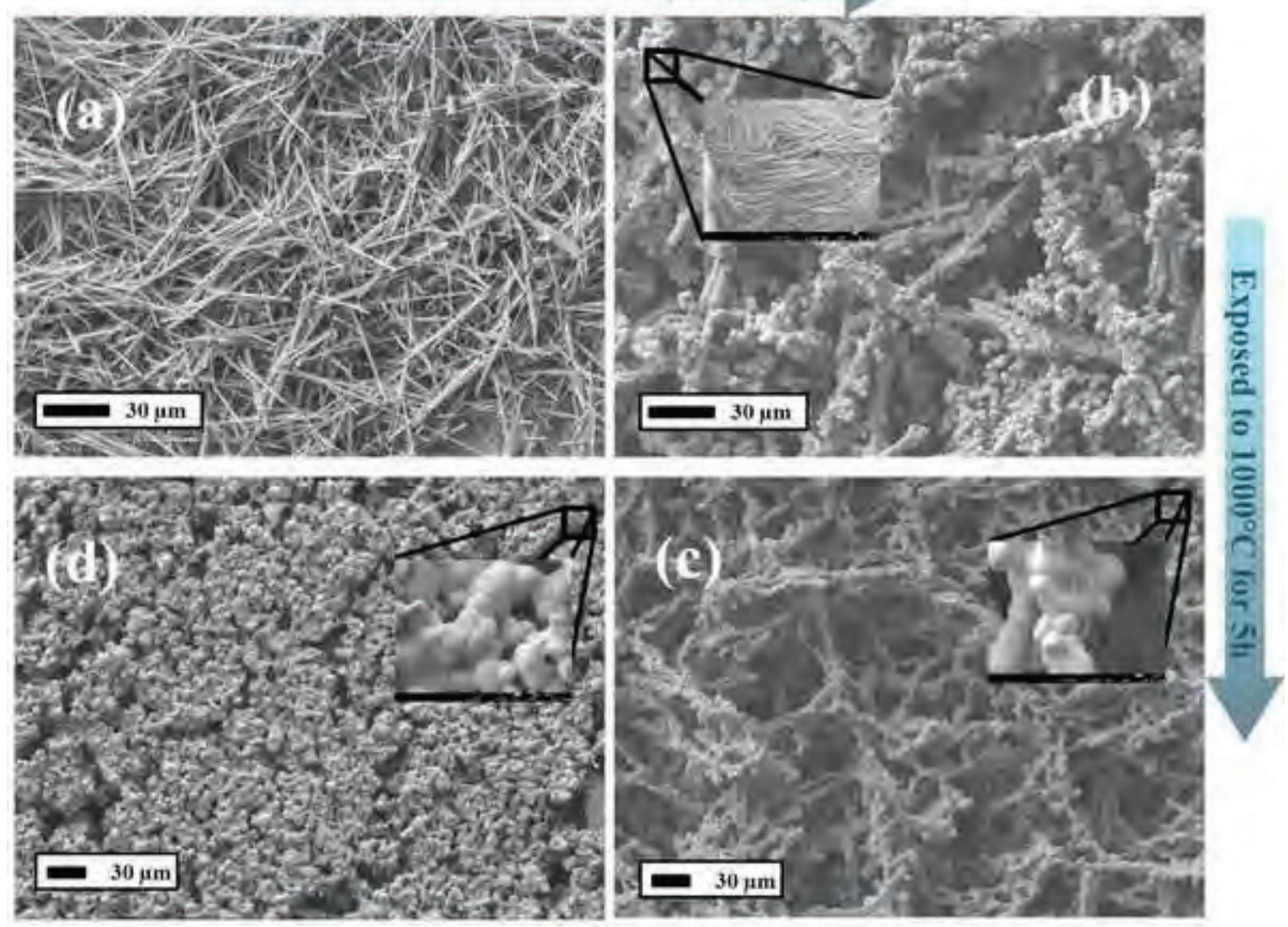

Microstructure

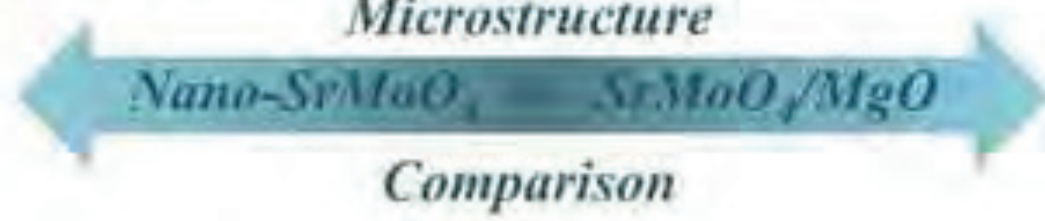




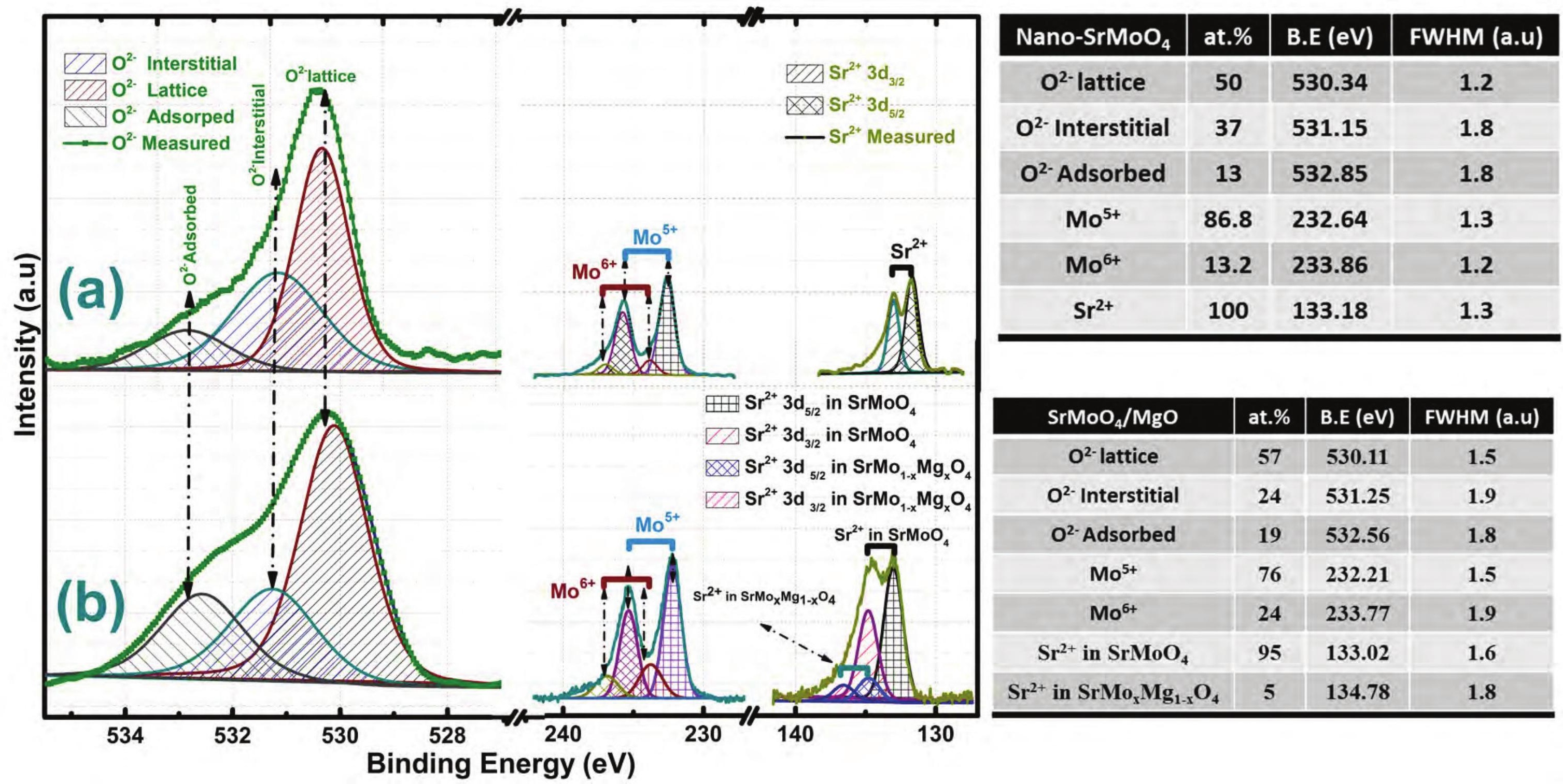




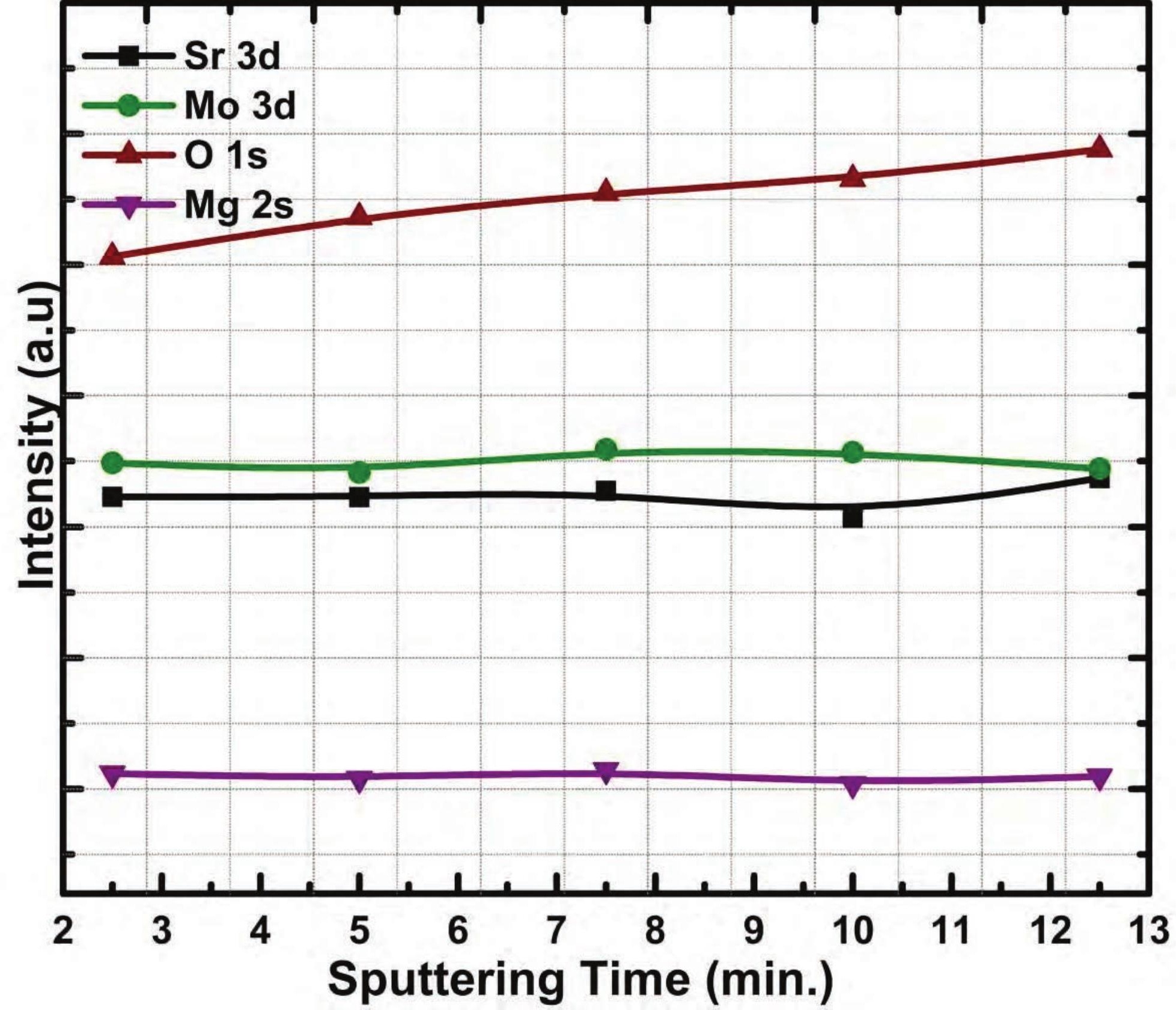



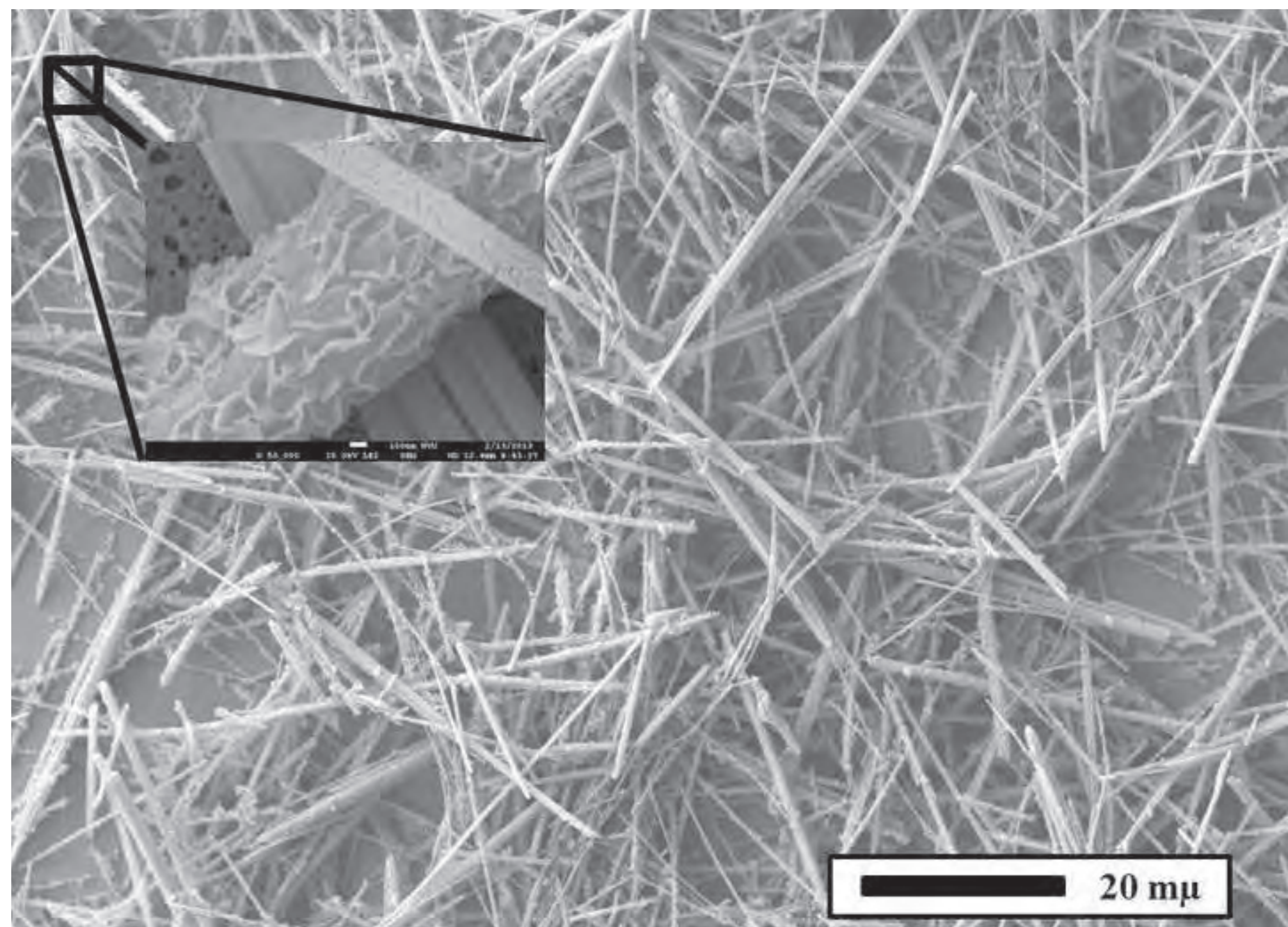

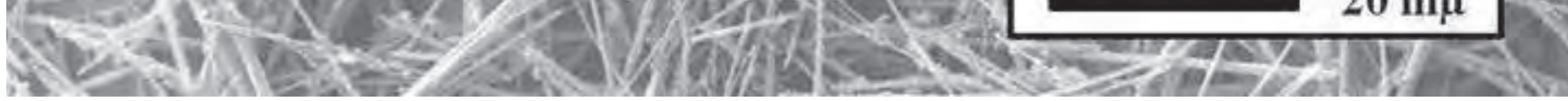




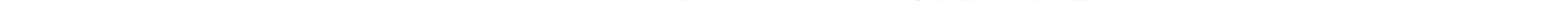




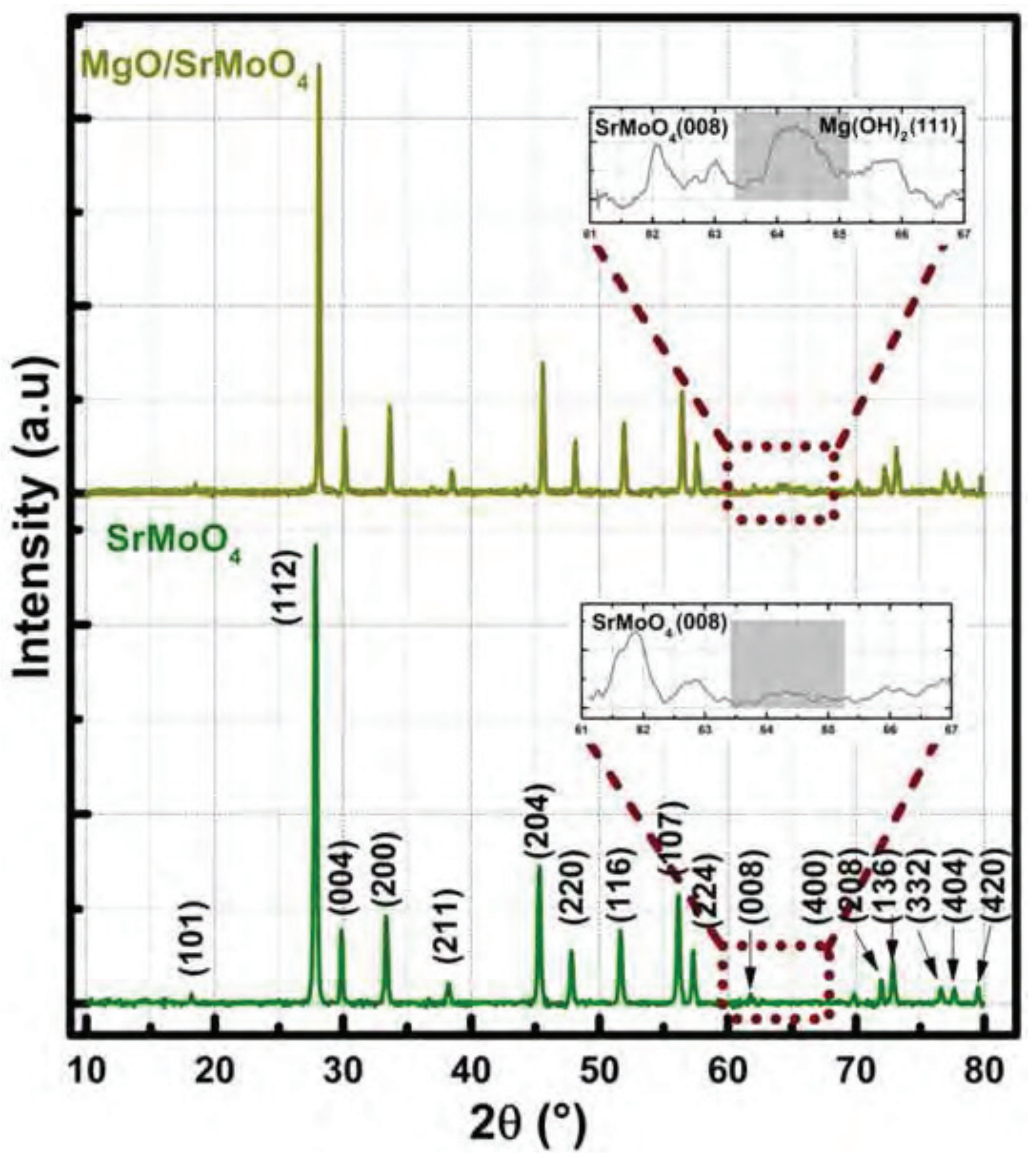




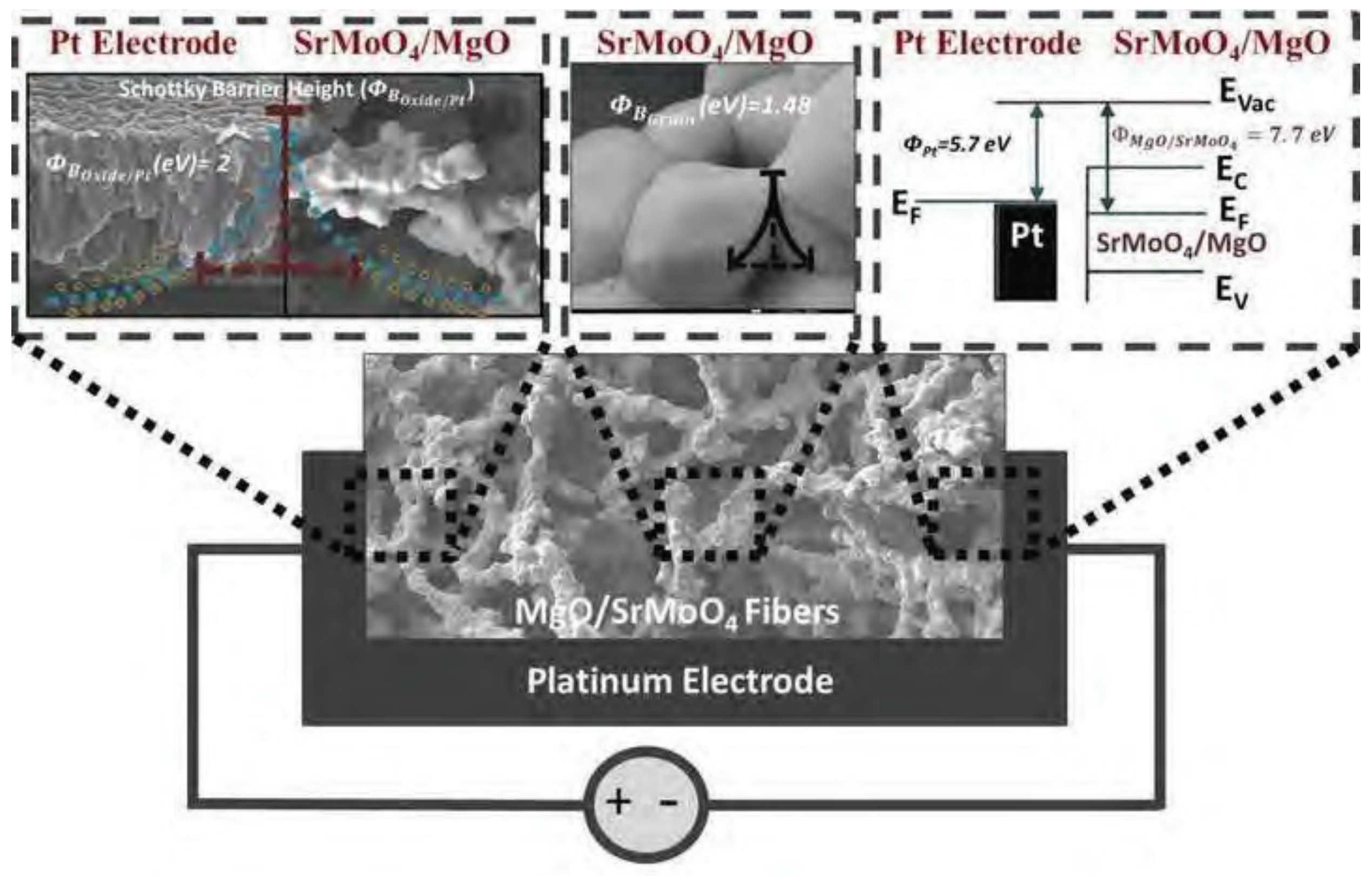




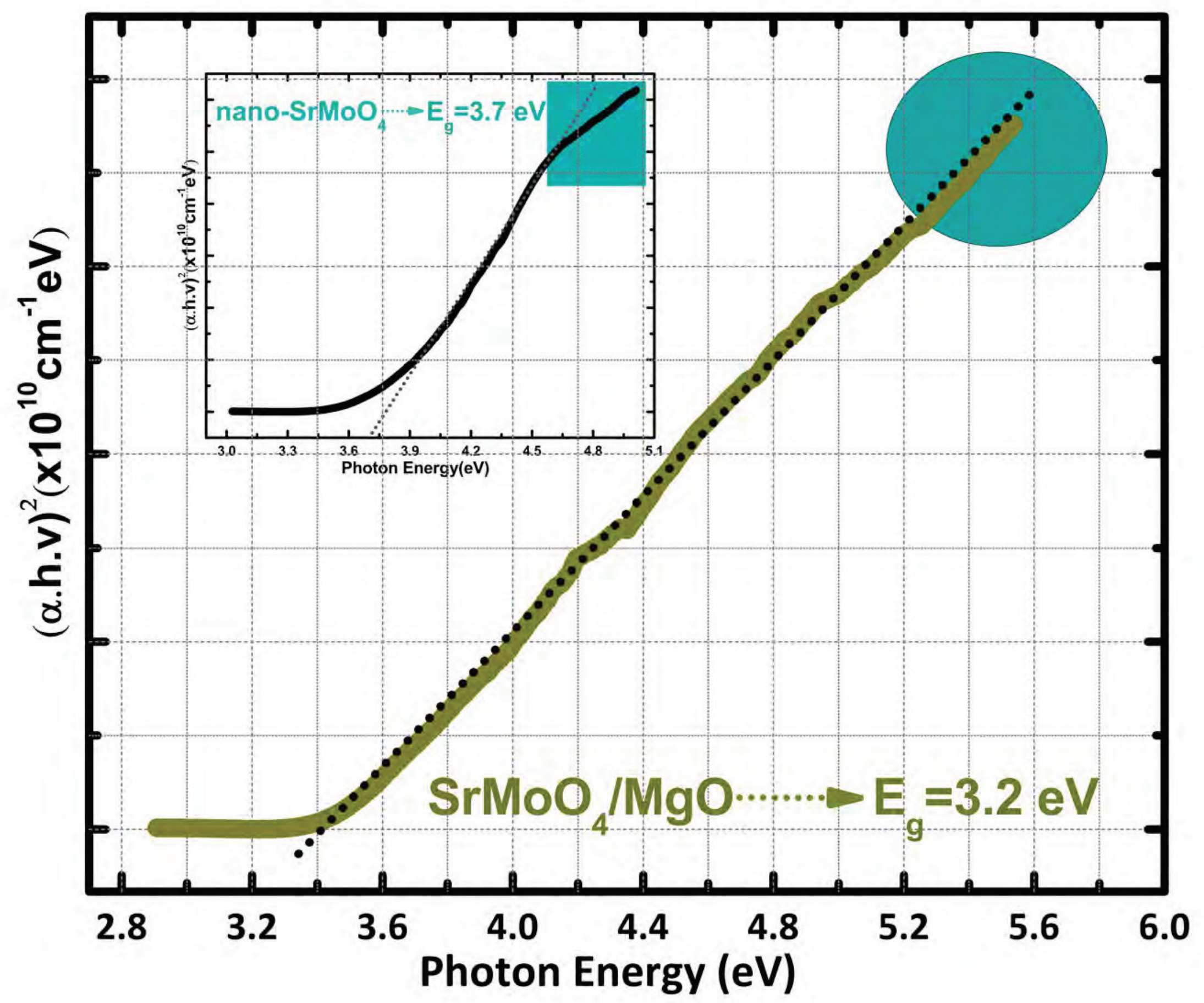




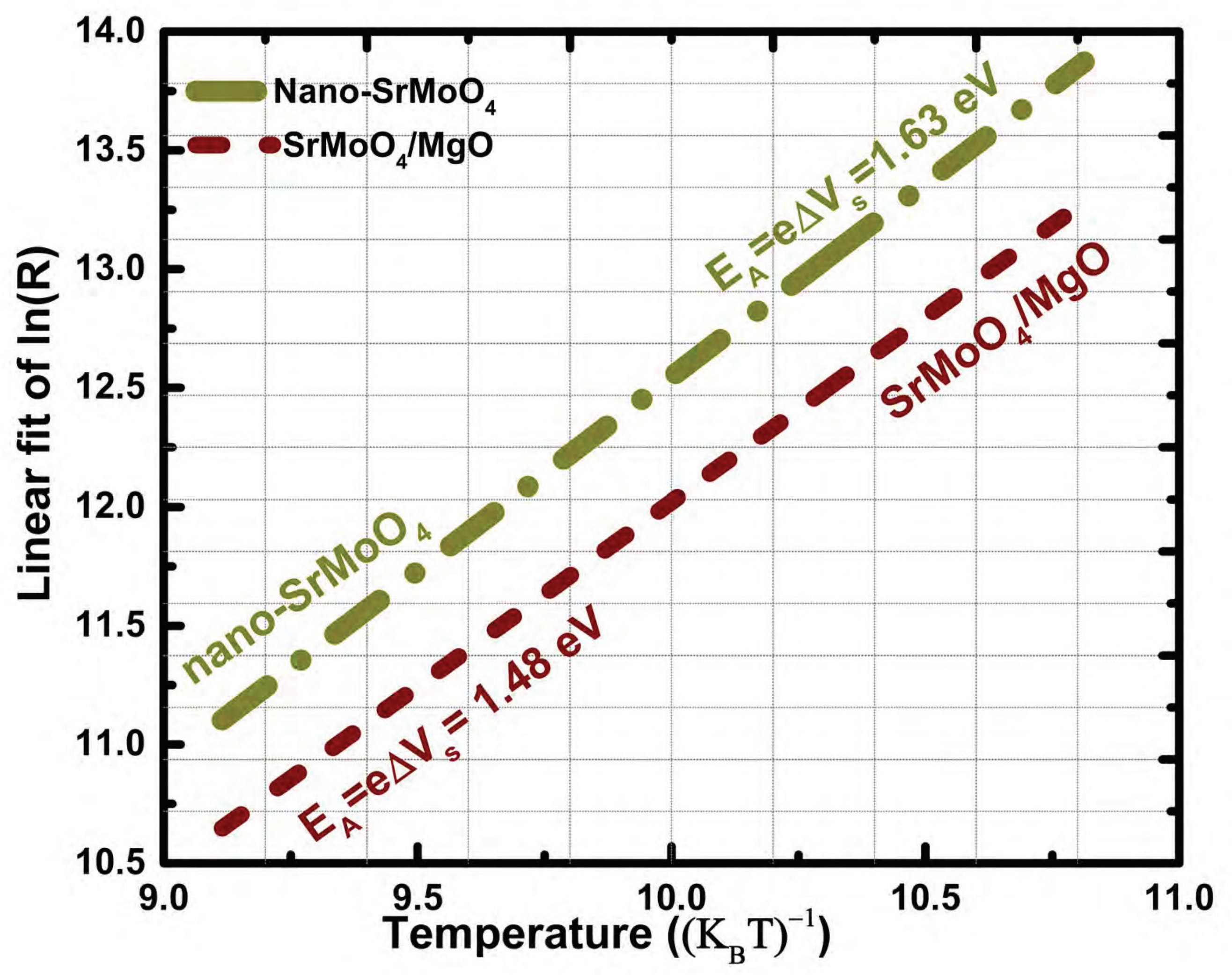




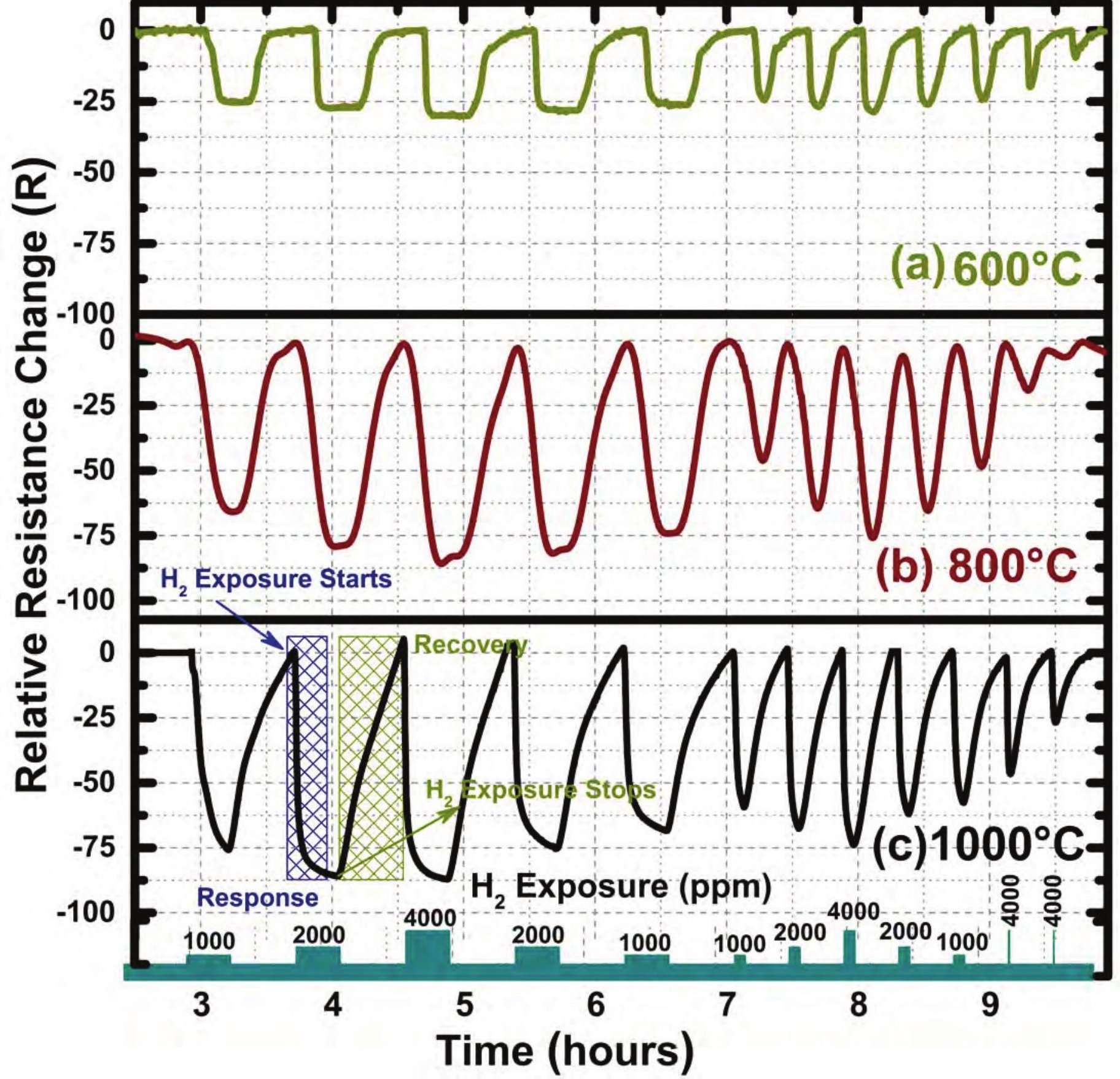




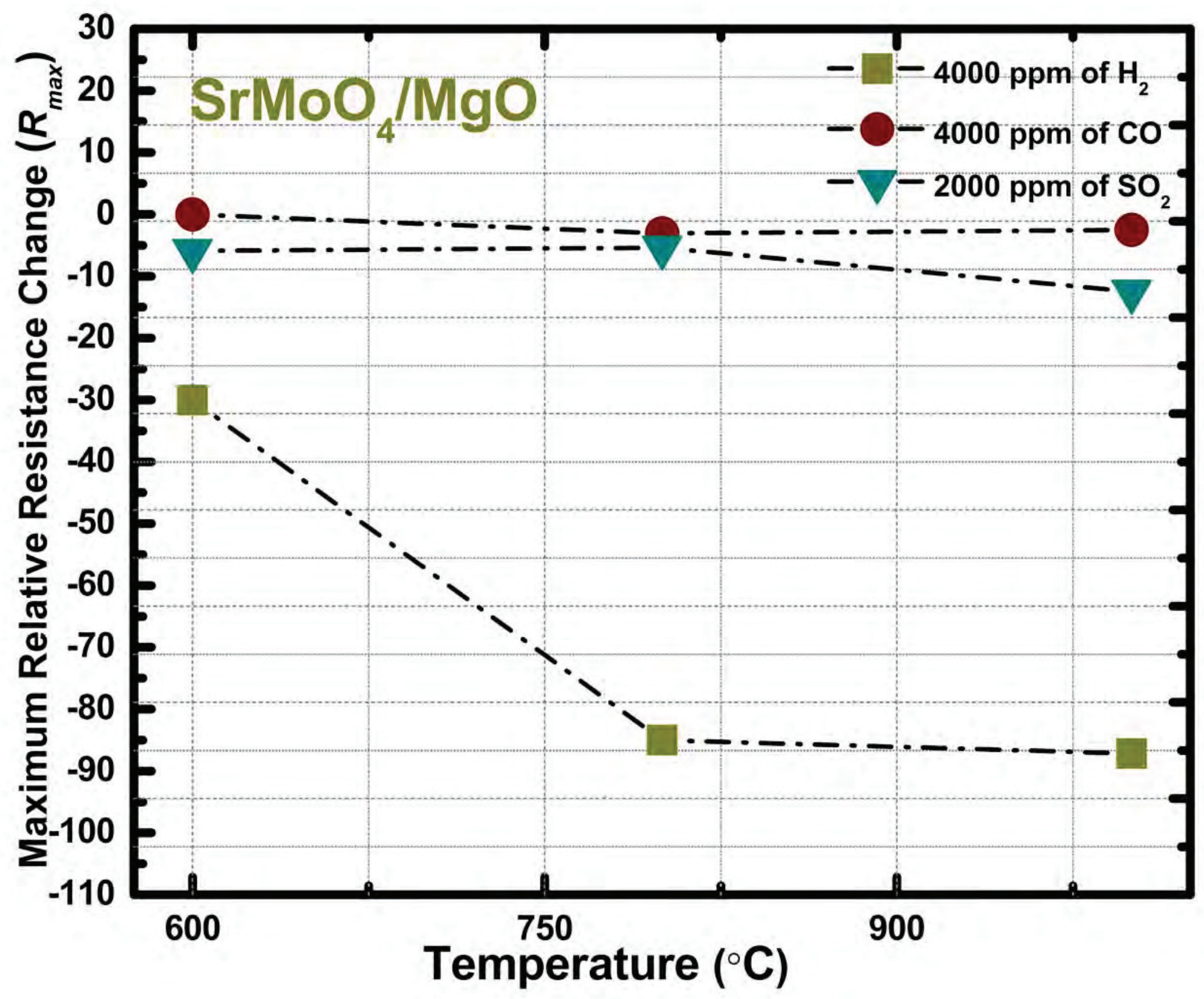




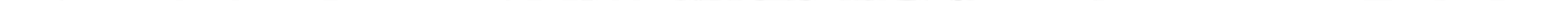




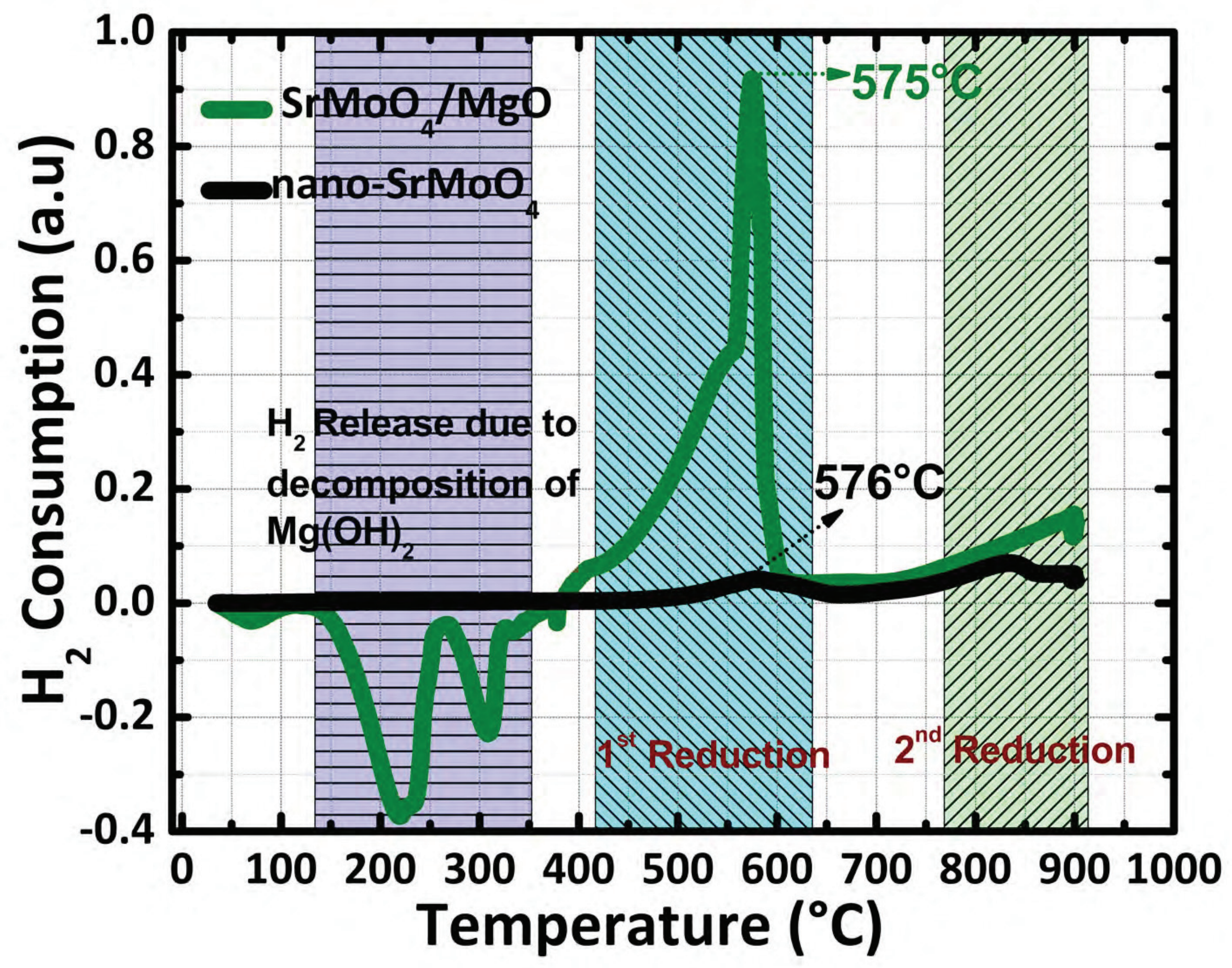



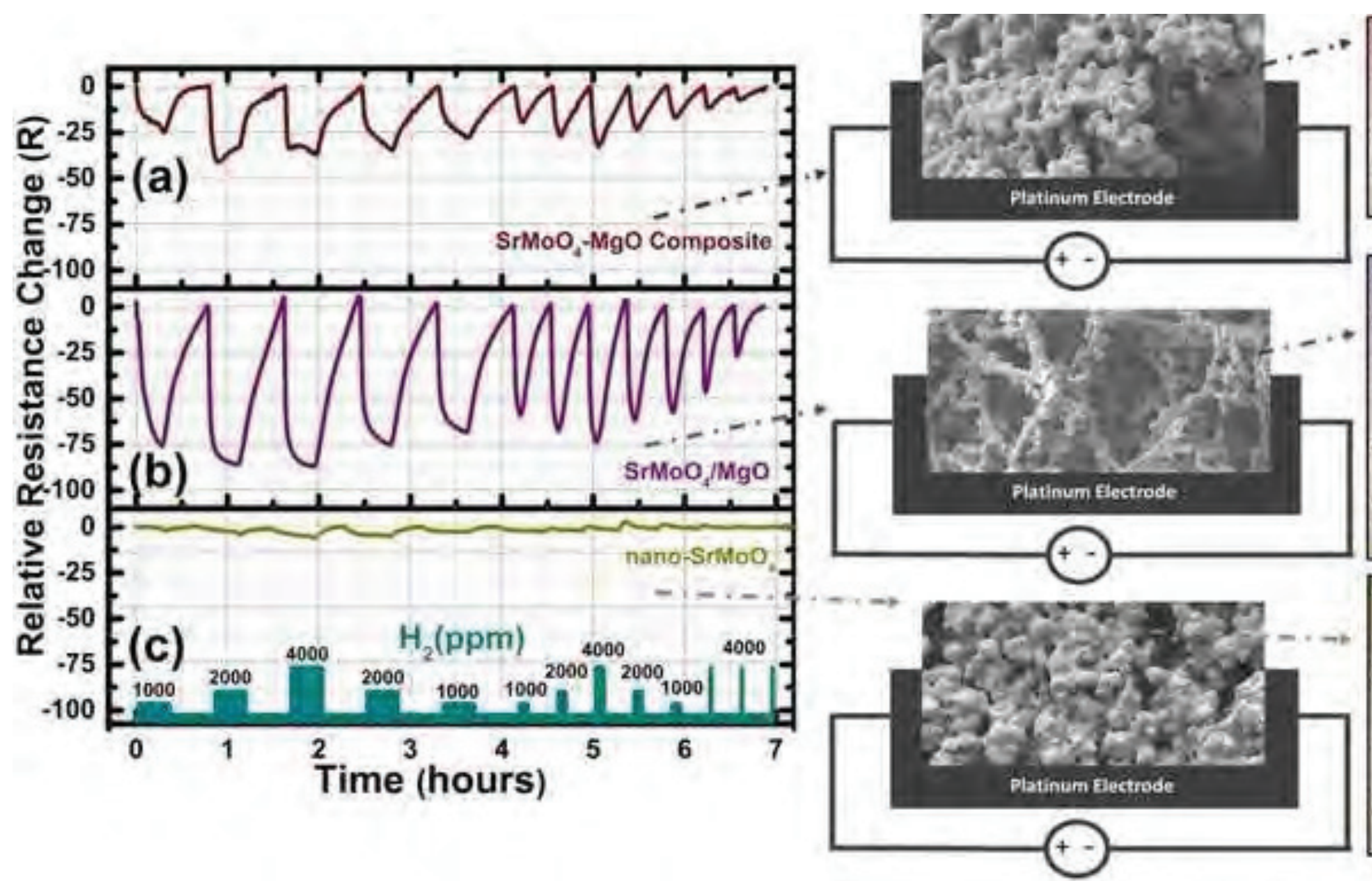

- Relative Seasoc Respoaser Midille

Porosity Levet: Middle Dispersed fine poris.

Relative $\mathrm{H}_{2}$ Adsorption:

Middle.

- Cufalycíe verivity for $\mathbf{H}_{2}$ Dissocbatioe: Yes

Helathe Sensor Respene: Higk

Porasity Level: High, open volume fibrous teaters.

- Relative $\mathrm{H}_{1}$ Alseorptions High

Electrode Interface Schattio

harrier $\left(\phi_{\text {fienden }}\right)=2.0 \mathrm{eV}$

Grain boandary Schottk

barrier $\left(\Phi_{n_{e n}}\right)=1.48 \mathrm{eV}$

Band Gap $=3.2 \mathrm{eV}$

Carabutic Netivity for H, Dissocistian: Yss

Relalive Senvor Rèponas: Lar

Ponsity Leveli Low.

Retaitic H, Advarption L.ou

Electrode Interface Schotiky

barrier $\left(\phi_{\text {monayin }}\right)=3.6 \mathrm{eV}$

Grais hounlary Scliotuky

burrier $\left(\Phi_{\mathrm{H}_{L \mathrm{e}}}\right)=1.63 \mathrm{eV}$

Haed Gap $-3.7 \mathrm{eV}$

Catalytic Activity for H,

Dissociatien: Not Apalicalde. 